九州大学学術情報リポジトリ

Kyushu University Institutional Repository

\title{
Morphologic Characters of the Weevil Head and Phylogenetic Implications (Coleoptera, Curculionoidea)
}

Morimoto, Katsura

Entomological Laboratory, Faculty of Agriculture, Kyushu University

Kojima, Hiroaki

The Kyushu University Museum, Kyushu University

https://doi.org/10.5109/2677

出版情報: ESAKIA. 43，pp.133-169，2003-03-31. Entomological Laboratory，Faculty of Agriculture, Kyushu University バージョン：

権利関係 : 


\title{
Morphologic Characters of the Weevil Head and Phylogenetic Implications (Coleoptera, Curculionoidea)
}

\author{
Katsura MORIMOTO \\ c/o Entomological Laboratory, Faculty of Agriculture, Kyushu University \\ and \\ Hiroaki KOJIMA \\ The Kyushu University Museum, Kyushu University, \\ Fukuoka, 812-8581 Japan
}

\begin{abstract}
As a result of our morphological observations of the weevil head, 26 characters are singled out for the phylognetic analysis of the principal families in Curculionoidea, of which 15 characters are newly employed for this purpose. These characters are examined in detail and their modes of development are speculated for making character matrix. The family relationship in Curculionoidea we inferred is mostly concordant with that in the cladogram by Marvaldi \& Morrone (2000), but is very different in the positions of Scolytidae and Platypodidae, and these are regarded as the independent families divaricated from an intermediate branch between the primitive and advanced families.
\end{abstract}

Key words: Morphology, phylogeny, head, Curculionoidea

The insect head is a composite structure of the acron and following six segments (Rempel, 1975), but all semblance of the segmented structures has been lost by their complete unification into a capsule, and only the postoccipital sulcus is retained as a true intersegmental line (Snodgrass, 1960). Various studies have been made to verify the homology of the head regions in relation to the protosegments from the standpoint of (1) comparative morphology, (2) embryology, and (3) fossil evidence. The morphological interpretation was well concluded at that time by Snodgrass (1935), but Ferris and his students (1942 1947) criticized his interpretation on the assumption that the basic structures of the insect head can be explained from the comparative morphology and a diagrammatic model of the basic structure was represented (Ferris, 1942). His logic of the interpretation was, however, not assented owing to the facts that

" the "sutures" of the head cuticle except for the postoccipital sulcus are of the 
secondary nature and the sulci and the internal ridges are nothing but the ecdysial lines and a device for strengthening the cranial walls (Snodgrass, 1947, 1960). Bitsch (1966) and the French school have paid efforts to clarify the head regions by the arrangement of the muscle origins to the respective appendages of the protosegements (Denis \& Bitsch, 1973), Weber (1952) made an integrated explanation for head including the nervous system of the brain, and Kukalova-Peck (1991) gave a schema of the head regions and appendages from the knowledge of the fossil evidence.

On the head of Coleoptera, a comprehensive study was first made by Stickney (1923), and the morphological interpretations were given by Cook (1943), DuPorte (1960) and Denis \& Bitsch (1973). On the head of the Curculionoidea, Hopkins (1911) gave the good illustrations of Pissodes strobi and Dendroctonus valens with morphological interpretations. This illustration and interpretation of Pissodes became well-known because of the quotations by Imms (1925) in his 'A General Text Book of Entomology', and by Marshall (1916) and Blatchley \& Leng (1916) in their monumental works on the weevil classification. Thus, the confluence of the gular sutures was accepted as characteristic of the Rhynchophora in general. Detailed morphology of the weevil head was made by Ting $(1933,1936)$ on the mouth parts, and by Dennell (1942) on Sitophilus granarius, by Dönges (1954) on Cionus scrophulariae and by Brack-Egg (1973) on Rhynchites auratus from the preparations in a series of thin sections. Dönges in this study (quoted by Denis \& Bitsch, 1973) made a morphological interpretation of the weevil head by making amendment of Snodgrass (1935), in which he recognized the hypostomal sutures and the pregular sutures on the underside of the rostrum, and the hypostoma between them in the schema of a prognathous insect head. Lyal (1995) explained the sutures and regions of the head after Snodgrass (1935) on the recognition of the subgenal suture (=hypostomal suture), the gular suture, the hypostomal-labial suture, the occipital suture, and the postoccipital suture. DuPorte (1960) and Snodgrass (1960) recognized only the gular sutures continuing to the hypostomal sutures on the underside of the prognathous insect head, and the other sutures or sulcus were explained as the secondary development of ridge-forming grooves as a device for strengthening the cranial wall.

As the previous works on the phylognetic analyses have been made on the rather limited information on the characters from a relatively small number of species for each higher taxon, the present studies of the morphology of the weevil head have been made with the purpose of giving a lot of new information in addition to the characters adopted by Morimoto (1962, 1981), Wood (1986), Thompson (1992), Zimmerman (1993, 1994a \& b), Kuschel (1995), Marvaldi \& Morrone (2000) and Marvaldi et al. (2002), and are hoped to amplify our knowledge of the phylogenetic relationships between the higher taxa in the Curculionoidea. 
Moreover, these contributions dealt mostly with the problems at the family and subfamily level, and the problems at the tribe and subtribe level remain unsolved especially in the family Curculionidae, which had been subdivided into 72 subfamilies and 143 tribes in Coleopterorum Catalogus (1929-1939), or 16 subfamilies and 195 tribes by Alonso-Zarazaga \& Lyal (1999). Thus, it is strongly hoped that the more knowledge will be added from the various fields for aiming the better understanding of the weevil higher system on the family- to subtribe-levels. Our studies have been still continuing on and additional information on these lines will be published hereafter in a series of paper.

\section{Methods and technique}

\section{Dissection technique}

The head was observed mostly by the ordinary methods under the compound $(\times 60 \sim 600)$ and stereoscopic microscopes $(\times 5 \sim 320)$, and partly by the scanning electron microscope, JSM-T2000. Drawings were made with the aid of an attached drawing tube or a calibrated eyepiece, and in most cases the hypopharynx was removed for drawing when the head was observed dorsally or internally.

Dissection was performed in the following technique. Dried specimens were macerated in a hot $10 \% \mathrm{KOH}$ solution for about 10 minutes or more according to the condition of specimen, and then washed in water. The head was removed and cut off it into dorsal and ventral pieces from both sides by using a cutting knife. This knife is hand-made by snipping off a narrow blade with sharp triangular apex from a double-edged steel razor blade. This blade can be hafted by using a match wood or a splinter of a chopsticks if necessary. The treated head was put on a small card, held on with forceps or fixed vertical on a piece of both-sided sticky tape, and then cut under the microscope at sides from the compound eyes posteriorly, and from the dorsal base of the mandibles posteriorly. The rostrum may be cut transversely into appropriate length in advance to the dissection when it is long and/or curved. The cut piece was mounted on a hole slideglass and observed. The head and rostrum are often highly sclerotized, blackish, hard and unable to observe through transparent light, but it may become pale or subtransparent when it is preserved in $\mathrm{KOH}$ solution for several weeks. The cut piece can be observed direct through a stereoscopic microscope in case of a large specimen with care of deformation by desiccation.

\section{Landmarks for the determination of homology and terminology}

To make a determination of homology on the ventral wall of the head in Coleoptera, the following structures can be regarded as the landmarks: postcoila, paracoila, 
hypostoma, gula and posterior tentorial arms. The terms we applied in this paper are followed principally after DuPorte (1960) and Snodgrass (1960) for the head since the continued postoccipital, gular and subgenal sulcus is recognized as a true intersegmental line, and Ting (1936) and Morimoto (1962) for the mouth parts. Several terms are newly proposed as noted in the following chapter.

\section{Specimens examined}

Specimens examined are enumerated in the appendix at the end of this paper.

\section{General morphology and terminology}

The external and internal characters of the adult have been studied by many authors, and good coding was made by Kuschel (1995) and Marvaldi \& Morrone (2000) for phylogenetic analyses. The characters adopted by these authors are, however, apparently insufficient for the head structures because of the lack of observation on the internal structures by dissection. The head should be regarded as one of the most important structure for inferring the origin of the Curculionoidea in relation to the development of the rostrum as in the following notes.

1. The rostrum: The rostrum is the more or less prolonged anterior part of the head in front of the eyes, which bears the mouth organs at apex and the antennae anywhere between the base and apex. Morphologically, the rostrum is defined by the anterior area of the head bearing internally the abductor and adductor tendons of mandibles, and the abductor, adductor and flexor tendons of maxillae, whereas the cranium bears the abductor and adductor muscles of mandibles, the abductor, adductor and flexor muscles of maxillae, the tentorium and the brain. Moreover, the rostrum has fundamentally two functions as the support of the mouth organs, one is for feeding foods, and the other is related to the oviposition.

2. The pleurostomal sinus: The pleurostomal sinus is a new term defining a concavity exterior to the base of mandible between the precoila and postcoila for giving its swinging space on each side. This sinus is at most shallow and less developed in Attelabidae, Scolytidae and Platypodidae (figs. 3,4), whereas in the other taxa it is deep, U-shaped and definite (figs. 1, 2, 5-8). The deep sinus receives the laterobasal prolonged part of the mandible in Anthribidae (figs. 1, 9, 41), membranous in Rhynchitidae (figs. 2, 11), and almost completely covered by the laterobasal lamellar lobe of the mandible in Brentidae, Apionidae, Nanophyidae, Curculionidae and Dryophthoridae (figs. 5-8, 43-45).

3. The hypostomal sinus: The hypostomal sinus is a new term defined a notch between the hypostoma and labium harboring the maxilla. This sinus is universal in 
Curculionoidea and important for the consideration of the relative sizes of the mouth parts and strengthening function by the paracoila.

4. The postcoilla: The postcoila is the socket of the ventral articulation of mandibles as the acceptabulum of the lower ball (figs. 18-29). Hopkins (1911) recognized three parts, the anterior condyle, the posterior condyle and the median fossa (fig. 22). The postcoila is located on the antero-interior margin of the hypostoma, $\mathrm{C}$-shaped with an opening on internal to antero-internal face, and the rim grasps tightly the postartis of mandible in Belidae and some genera examined in the primitive families (figs.18-20). From this condition, the postcoila may be developed into two directions: one is a direction to a hemispherical fossa as seen in most Curculionidae, Dryophthoridae, and Brentidae, having the hypostoma more or less produced apico-internally to apically in a triangular to sharp process in front of the anterior condyle (fig. 26), and the anterior and posterior condyles are often contiguous or fused so as to make a ringed periphery of the fossa (figs. 25-29); the other is seen in Scolytidae and Platypodidae that the postcoila is so simple as a shallow bowl lying on the anterior face of the hypostoma, and hinged to the subconical or subtriangular postartis of the mandible (figs. 22-23). Thus, Scolytidae and Platypodidae are easily distinguished from Curculionidae (including Cossoninae) by the absence of the hypostomal process (=hypostomal tooth of Kuschel, 1995) in addition to the absence of the pleurostomal sinus in external observation (figs.3, 4, 77). In Anthribidae and Attelabidae, the postoila is shifted its position to anterior or antero-internal face of the hypostoma owing to the development of the broad bracon connecting the interior basal portion of the postcoila to each other (figs. 23-25, 78, 79).

5. The paracoilla: The paracoila is the pouch for receiving the cardo of the maxilla as a fulcrum near the bottom of the hypostomal sinus (figs. 81-92, 104-109). The parartis of the cardo is prolonged internally across a concave dorsal margin of the outer wall in most Curculionoidea. In Anthribidae, the oral cavity is divided dorso-ventrally by the hypopharyngeal bracon (figs. 56,78 ). This is a broad wall connecting the hypostomata with a pair of holes for the parartis and a trough-like ridge from the hole for holding the caudal margin of the cardo. Somewhat similar state is present in Attelabinae, but the hypopharyngeal bracon is of a narrow band connecting the hypostomal arms via hypopharyngeal sclerite (fig. 79). Great modification is observed on the position of the paracoila in Platypodidae for receiving the cardo lying at right angle to the stipes exteriorly (figs.107-109). The hypostoma of this family is inflected inwards and prolonged inwards as a lamella and connected broadly with the posterior tentorial arms so as to form a broad membranous wall when viewed internally. Similar condition is present in Scolytidae, but the posterior tentorial arm terminates at the hypostomal suture and not embossed from the ventral wall at anterior 
margin (figs. 104-106), whereas in Platypodidae the tentorium is continuous with a lamella of the hypostoma in embossed condition leaving an incurved faint suture on each side.

6. The Hypostoma: The hypostoma is the part of the subgenal margin of the cranium posterior from the mandible to the submentum including the postcoila, paracoila, and hypostomal process (figs. 80, 81, 83). In 'Curculionoidea, the hypostoma is a narrow plate marked internally by a strong ridge in general, but often not limited from the postgenae owing to the degeneration of the hypostomal (=subgenal) suture, or often inflected and invisible from ventral side, or conglutinate with the marginal ridge.

7. The hypopharyngeal bracom: The preoral cavity is divided dorso-ventrally by the hypopharyngeal bracon connecting the hypostomata only in the Anthribidae (figs. 56, 78) and Attelabidae (fig. 79), of which the former is a broad wall and the latter is a narrow bridge. As this bracon is not found in the other families and the out-groups, this may be autapomorphic to these families, but the character conditions are different, namely the bracon is broad so as to almost completely divided the preoral cavity in Anthribidae with a pair of ovate holes for passing the parartis of cardo (fig. 56), whereas in Attelabidae, the bracon is a narrow bridge dividing the anterior part of the preoral cavity, and the paracoila is present at the bottom of the hypostomal sinus. As these bracon lies transversely, the mandibles and maxillae move transversely in consequence in these taxa (figs. 9, 10).

8. The labrum: The labrum is only present as a movable flap in the Anthribidae (figs. 30-34) (except Bruchela) and Nemonychidae (fig. 37), and the setal arrangement on the dorsal surface is comparable to that of the larvae in some species (figs. 31, 34). In Bruchela, the labrum and clypeus are tightly conglutinate together with the anterior margin of the frons (fig. 36).

9. The clypeus: The clypeus is usually short in front of the epistomal ridge, which is a deep inflection inwards, and the basal margin is often demarcated by a transverse shallow depression or sometimes by a row of setae in some taxa, or the demarcation and the clypeus itself is completely obliterated in most taxa. Each side of the clypeus is often more or less depressed, which is termed here as the paraclypeal depression, and this depression often has a small tuft of setae. The latter is called here as the paraclypeal setae. The paraclypeal depression is a tentorial suture for receiving the anterior tentorial arm (vide Ferris, 1942).

10. The mandibles: The mandibles are short and stout, and hinged to the apical margin of the rostrum by well-developed dorsal and ventral articulations, and move transversely by abduction and adduction produced by abductor and adductor muscles attached to very slender tendons from the dorsal wall of the cranium in Anthribidae and Attelabidae, but the mandibles in the most families are modified to occlude more 
or less obliquely upwards owing to the shift of the postcoila ventrad accompanying the vertical translocation of the maxillae in the course of the development of the head into the rostrum. They move more obliquely in some Conoderinae (=Zygopinae), Baridinae and almost vertical in Curculionini (figs. 9-17).

The mandibles occlude internally in general, but are of abducent type in some genera such as Parallelodemas and Linogeraeus in Baridinae, Protocerius, Macrocheirus, Cyrtotrachelus, Otidognathus and Ommatolampus in Dryophthoridae. In these cases, the mandibles may be dentate externally, the preartis and postartis are shifted more internally and the abductor tendon becomes much greater in general.

The preartis or anterior condyle of articulation consists of a semi-circular, convex ball surrounded by a trough-like acceptabulum, and tightly fits into the precoila of the head, which is crescent-shaped and open posteriorly. These structures are common throughout the superfamily, but the dorsal ball-like condyle is always torn off when dissected in Anthribidae (vide Ting, 1936).

The postartis or posterior condyle of articulations can be grouped into three types according to the shape and directions in Curculionoidea.

(1) The postartis is short cylindrical with hemispherical apex and directed oblique to the axis of the mandible in Nemonychidae, Anthribidae, Attelabidae and Rhynchitidae (figs. 38-41, 47-50).

(2) It is only an ogival or conical prominence in Scolytidae and Platypodidae at basal margin of the mandible (figs. $42,53,54$ ).

(3) The postartis is spherical with constricted hollow around the base in Brentidae, Apionidae, Curculionidae and Dryophthoridae, and rectangular in direction to the axis of mandible and lies a little anterior to the basal margin of the mandible in position (figs. 43-45, 52).

The mandible can be classified into three types according the structures of the lateroposterior corner in relation to the insertion of the abductor tendon as follows:

(1) The laterobasal corner is prolonged into a semiglobular condyle in Anthribidae, into which the abductor tendon is attached (figs. 41, 49, 50).

(2) It is simple and not prolonged in Attelabidae, Rhynchitidae, Scotytidae and Platypodidae (and also Nemonychidae and Belidae) (figs. 38-40, 46-48).

(3) Its exterior surface is inflected between the articulations, and the area basal to the inflection forms a smooth curved surface in an exterior view, which is a lamellar extension (lateral plate of mandible in Dennell, 1942) covering the joint of the abductor tendon to the mandible in Brentidae, Apionidae, Curculionidae and Dryophthorinae (figs. 43-45, 52).

The mandibles are fundamentally curved inwards at their exterior surface, and the inner margin faced parallel to the opposite constitutes the inner concavity between the dorsal 
and ventral cutting edges, and the mola is present at the base of the inner surface, which is well developed and faced to the opposite in Anthribidae and Nemonychidae (figs. 38, 40, 46, 51), and the mola-like structure is present in some Attelabidae and Scolytidae. The rasp-like mola is secondarily developed in some genera of Cossoninae at the flat intererior basal region of the mandible, which lies one upon another when rested (fig. 52).

The apex of the mandible is more or less sharply pointed to form the apical tooth. The dorsal cutting edge bears the dorsal tooth, which is usually smaller than the apical tooth, and the ventral cutting edge usually bears the ventral tooth in the fundamental structure (fig. 41). These teeth are usually easy to identify by their positions, but are often difficult in the weevils arranging them in a straight line with the mandibles occluding oblique upwards. In the latter weevils, the ventral cutting edge may shift close to the lateral margin accompanying with the moving of the ventral tooth to the dorsal margin, and the cutting edge bears three teeth and two notches in consequence (fig. 43).

The exterior surface of the mandibles has a longitudinally depression with characteristic setae in Anthribidae, Attelabidae and Platypodidae (figs. 9, 10, 13), and the remnant of these impression can be traceable in Nemonychidae and Rhynchitidae (figs. 40.46, 48). The lateral depression of the mandibles prolonged basad in Attelabidae, Scolytidae and Platypodidae as a small but sharp depression at the base, which receives a prominence from the pleurostomal margin (figs. 10, 12, 13). This type of depression and prominence are only present in Viticis and Tivicis, both in Viticiini of Curculionidae so far as we have examined other than these families.

11. The maxillae: The maxilla consists fundamentally of the cardo, stipes, lacinia, galea, palpiger and the palpus. All parts are observed in Nemonychidae, Belidae Anthribidae, Attelabidae, some Platypodidae and Sitonini. The lacinia has fused with the galea and forming the mala in the other groups, but the demarcation of these parts can be traceable often by the different arrangement of marginal setae (fig. 62) and sclerotization. The palpi are four-segmented in the Nemonychidae, Belidae, Anthribidae and Attelabidae, and three-segmented in the other families, or twosegmented in the Apioninae and some Curculionidae. The apical segment bears several nipple-like papillae at the apex and some oblong sensory pores on the wall. These pores are parallel in arrangement (figs. 60-62) except for the Playpodidae, of which the sensory pores are arranged radiately on a large flat area (fig. 63). These pores are parallel but fewer in Nemonychidae, Rhynchitidae and most Anthribidae (fig. 56), and arranged in a paired oblique rows on exterior side in some Anthribidae (fig. 57).

The maxillae move between the mandibles, hypostoma and labium, so that the general shape is determined by their relative positions and the movable space among them. 
They move in a horizontal plane in the Anthribidae and Attelabidae, nearly horizontal in the Scolytidae and Platypodidae, and almost vertical in the Brentidae, Apionidae, Curculionidae and Dryophthorinae. (figs. 9-17)

The maxillae of Platypodidae are characteristic in the position of cardo almost rectangular to the stipes (figs. 108, 109) $\left(180^{\circ}\right.$ shifted from the condition in Anthribidae as shown in fig. 56), slender and compact from the stipes to mala and palpus, and separated galea and lacinia in some primitive genera (fig.63; Ting, 1936, p. 111, fig. 79; Wood, 1986, p. 8, fig. 6).

12. The labium: The labium of Coleoptera is fundamentally divided into three regions known as the prementum, mentum and submentum, but the latter two parts are completely fused in the superfamily Curculionoidea, so that there are two distinct parts present, the prementum and the postmentum. They are usually lying on the same plane, but the postmentum is declivitous in the Scolytidae, Platypodidae and some Curculionidae at the junction to the prementum. It is narrowed and deeply depressed at base of the premtnum in Anthribidae and some Cossoninae.

The prementum is a well-scleritized plate and visible in front of the postmentum from the ventral side in all weevils except for those in Dryophthorinae, of which the prementum is more or less retracted into the oral cavity and invisible externally (figs. 74-76). In front of the insertions of the labial palpi at sides, the prementum is prolonged anteriorly as an membranous area with dense setae (fig. 65) or sclerotized area without setae on ental surface (figs. 64, 71) in Nemonychidae, Belidae, Anthribidae and Rhynchitidae, which is often termed as the ligula, whereas in the other families, the ligula is defined as an membranous area of the prementum with dense setae on ental surface. In the latter case, it is continued and prolonged anteriorly from the hypopharynx between the palpi (fig. 83), and their homologue may not be verified.

The labial palpi may primarily three-segmented and attached to the ventral surface of the prementum at sides as seen in Anthribiae, Nemonychidae and Belidae (figs. 6466). In accordance with the development of the rostrum accompanying the drilling movement, the labial palpi may translocate to the anterior margin of prementum in the majority of the Curculionoidea, or the palpi are shortened and inserted into the cavities on the ventral surface of the prementum as in Attelabidae, Cleoninae and Eugnathus (figs. 67, 68) or the cavities on the internal surface in Brentidae (figs. 72, 73). The palpi may be reduced the segments from three to two or one, or to mere papillae, or completely absent in some Attelabidae and some Curculionidae (figs. 68, 69).

The postmentum is various. It is very broad in the Anthribidae, Rhynchitidae and Platypodidae (figs. 65, 66, 67, 70, 71, 107,109), small and hollowed in the Scolytidae (figs. 77, 104-106), short to very short in the adelognathous Curculionidae, or long and slender in many groups. 
13. The apodemes for supporting the muscular tendons of the mandibles: The mandible has the abductor and adductor tendons, which are slender and wire-like structure, passing in the rostrum, and continued to the respective muscles originating from the cranial wall in the head. In accordance with the prolongation of the rostrum into a slender tube and more or less curved ventrally, the apodemes may have developed for supporting the tendons in the rostrum from the ventral wall (Dennell, 1942; Dönges, 1954; Brack-Egg, 1973). These apodemes often can be observed as sclerotized longitudinal lines when viewed internally through a transparent light in the weevils with long rostrum, but are usually difficult to distinguish in older individuals, and may not be present in the weevils with short rostrum in general. In the genera Polydrusus (fig. 91) and Phyllobius (fig. 90), these apodemes lies transversely at the base of rostrum, which are seen as a pair of transverse sulci on the underside in external observation. These apodemes were regarded to originate from the gular sutures (McClenahan, 1904), from the hypostomal sutures (Dönges, 1954), or the hypostomal and pregular sutures (Brack-Egg, 1973). On the contrary to these theories originating the apodemes from the fundamental sutures, Dennell (1942) stated that these were probably to have arisen only in relation to the tendons and are of purely functional significance. Our observations on the apodemes, however, have something to be insufficient at present and we reserve to get in touch upon the detail in this paper.

\section{The strengthening structures of the rostrum}

The rostrum has the mandibles, which are the device to get food and to make oviposition hole by occlusion and/or drilling in a vertical or rotatory motion. These motion can be possible by strengthening the rostrum from the breaking in the following ways: (1) inflection and formation of ridges, (2) formation of bridges; (3) sclerotization of the paracoila at the bottom of the hypostomal sinus, and (4) development of the postartis and postcoila of the mandibles as in the followings in Curculionoidea. (vide figs. 79-92, 105, 106 for the character numbers in circle).

(1) Inflected strong ridge along dorsal margin of rostrum, or clypeofrontal suture if clypeus present, and continued to the precoila.

(2) Anterior tentorial pits, which are usually obliterated, but each can be traced as a short ridge interior to precoila often with a paraclypeal setal tuft.

(3) Pleurostomal ridge along the mandibular sinus between precoila and postcoila.

(4) Hypostomal margin, ridged and/ or inflected. In close examination, two ridges can be recognized, one from the inner (dorsal) condyle and the other from the ventral (posterior) condyle of the postcoila, and the narrow area between them bordering the maxillary space is the true hypostoma. The hypostoma is often concave trough-like for 
receiving the stipes.

(5) Hypostomal bracon, which is a broad wall completely dividing the oral cavity dorso-ventrally and conspicuous in Anthribidae, narrow bridge connecting the hypostoma and the median plate in Attelabidae, but not present in the other families.

(6) Paracoila as a most important strengthening structure at the bottom of the hypostomal sinus. It is a simple trough-shaped in the primitive condition (fig. 81), but is strengthened by the thick sclerotized wall in the advanced condition and often pocketlike (figs. 82-86). This is not developed in Scolytidae and Platypodidae (figs. 104109).

(7) Transverse ridge connecting paracoilae on the wall of postmentum.

(8) Inflection of lateral and anterior margin of postmentum.

(9) Transverse ridge connecting paracoilae across the base of hypopharynx above the wall of postmentum.

(10) Short ridge prolonged caudad from respective paracoila.

(11) Short ridge branching from the median part of hypostomal ridge directing exteriorly behind postcoila.

(12) Transverse bridge connecting the pregular sutures above the wall. This is characteristic to Scolytidae.

(13) Broad U-shaped ridge between pleurostomata .

(14) Gular and pregular ridge.

(15) Ridges as the dorsal and ventral margins of the antennal scrobes.

(16) Circumocular ridges.

(17) Apodemes produced internally from depressions or sulci on the underside of rostrum.

(18) One to three pairs of foveae behind the bottom of the hypostomal sinus (hypostomal punctures of Hopkins, 1911). This fovea is a simple concavity and no special accessory is present on the inside.

The strengthening structures are shown in figs. $78-92$ and $105-106$ by denoting the correspondent number in circle. The ridges in (7) and (12) cases may have developed transversely along the inflection of postmentum or rostrum at the base in some taxa and various in strength if present.

These structures have not been compared in detail from the view point of phylogeny, but comments can be given from our limited examination as follows: (1), (2), (3), (4), (6) and (8) are all present in species examined. (5) is characteristic to Anthribidae, which have a broad hypostomal septum completely dividing the oral cavity dorso-ventrally; similar septum is present in Attelabidae (s. str.), but much narrower and only dividing the anterior part of oral cavity; and no such septum is present in the other taxa examined. (7) and/ or (9) is often associated with (10) in many 
species in the Phanerognatha examined, but (7), (9) and (11) are absent in Belus, Dicordylus, Rhinorhynchus, Metrioxena, Rhynchitidae, Antliarrhinus, etc.

\section{The gula and tentorium}

The gula is a median ventral plate of the head confluent with the postmentum between the posterior tentorial pits and bordered laterally with the gular sulcui or sutures. The gular sulcus is morphologically a part of the postoccipital sulcus and continued anteriorly to the subgenal sulcus (Snodgrass, 1960). The tentorium of Coleoptera is fundamentally similar to that of Orthopteroid insects, and consists of a pair of anterior arms, a pair of posterior arms, the dorsal tentorial bridge connecting the posterior arms, and the dorsal tentorial arms arising as the dorsal branch of the anterior arms and extending to the forehead (fig. 94). In Curculionoidea, the anterior arms are obliterated in all taxa so far examined except Belidae, which have the remnant bases on the tentorium, and the dorsal tentorial arms may be melted away in some cases excepting the bases when treated with $\mathrm{KOH}$ solution. The other structures can be grouped as follows (fig. 93):

I. The Bellid-group: A paired gular sutures are always present, and far distant from the hypostoma.

1. Belidae: The gular sutures are paired, long, posterior arms are very broad, tentorial bridge is complete, bases of anterior and dorsal arms are present (fig. 95).

2. Metrioxeninae: The gular sutures are very short, posterior arms are almost as broad as tentorial bridge, dorsal arms are present.

3. Nemonychidae, Anthribidae, and Aglycyderinae: The gular sutures are very short and only seen as a pair of foveae at the base of head on the underside, and the tentorium is completely obliterated leaving a pair of processes (figs. 96, 97).

III. The Scolytid-group: The gular sutures are Y-shaped in general, or exceptionally paired in some primitive genera.

4. Scolytidae: The gula is reduced to a line on about basal two-thirds, and thus the gular sutures are Y-shaped [two gular sutures are present in some Gnathotrupes (vide Wood, 1986; p.76, fig.12)]. The posterior tentorial arms continued to the divaricated part of gular sutures (pregular sutures of Wood, 1986) at its anterior part (figs. 104106).

5. Platypodidae: The gula is somewhat similar to that of Scolytidae, but is highly specialized to meet the sheet-like extension of the hypostoma from the paracoila, and thus the "pregular sutures" continue to the hypostomal margin at the bottom of hypostomal sinus on each side of postmentum when viewed ventrally. The distinct gula is present in the female of Crossotarsus nipponicus (fig. 109). 
III. The Curculionid-group: The gular sutures are completely coalescent to form a linear sulcus, and the posterior armes are triangular in dorsal aspect. Desmidophorus is the only exception as noted in the following:

6. Desmidophorus: The gular sutures are shortly divaritated at anteior part in a Yshape, but the condition is very different from that of Scolytidae by the widely distant tentorium from the hypostomal margin (fig. 98).

7. Brentidae, Ithyceridae, Antliarhinidae, Apionidae, Attelabidae (except Apoderini), Curculionidae, and Dryophthoridae. The gular sutures are completely linear, and the tentorium is visibly triangular when viewed internally by complete coalescence at the base (gula), tentorial bridge is present or absent. In some Apionidae with constricted head, the tentorium has the narrow caudal part and is visibly parallelsided when viewed internally. (figs 99-101)

8. Apoderini: The posterior arms of tentorium originate only from the gular suture and far remote from the postoccipit owing to the strong constriction at the neck (figs. $79,102,103)$.

\section{Notes on some larval structures}

The larvae of Curculionoidea are generally small in size, soft in body and many important characters are apt to be reduced and simplified, and consequently difficult to extract the systematic characters from our traditional method of examination. Lekander (1968) claimed that Scolytidae may possibly be polyphyletic on the larval characters and a certain uniform external shape of body is obligatory developed on account of the mode of life under the bark and in the wood. A terminology for the taxonomic characters of the weevil larvae was well documented by Anderson (1947) and May (1994), and their characters were coded for the phylogenetic analysis of the higher taxa by Kuschel (1995), Marvaldi (1997), and Marvaldi \& Morrone (2000). We do not intend referring these characters again, but to touch upon the cervical plates as in the followings.

The cervix of the weevil larvae is a membranous and flexible region of the trunk between the head and prothorax. It is divided by a faint median constriction into an anterior and a posterior parts, and are hidden under the overlapping anterior margin of prothorax. The anterior part of the cervix is often sclerotized into a triangular or sectorial plate on each side, and often more or less sclerotized or thickened at the dorsal side. Though the former sclerites were termed by May (1994) "the postocciptical condyles", they conglutinate to the postocciput direct to or through a linear pale margin in some cases (fig. 125). The longitudinal muscles from the prothorax are not attached anteriorly on the postocciptical condyles, but on the postoccipital ridge of the cranium. Thus, they belong apparently to the cervix and are 
newly termed here the cervical plates. When the cervical plates are firmly conglutinate to the postocciput without a pale linear part, the head is apt to retain them after removing the head from the prothorax in the ordinal dissection method in Curculionidae (figs. 119-124), but in the cases when the intermediate linear areas between the postocciput and the cervical plates are membranous, the latter plates may remain on the cervix by removing the head from the prothorax without care in Cylas, Apion, Rhynchophorus etc. On the contrary to these families, the cervical plates are absent in the larvae of Anthribidae, Attelabidae, Rhynchitidae, Scolytidae and Platypodidae so far as we have examined (figs. 110-117). In the latter taxa, the postocciput is visibly straight at its posterior contour when viewed laterally, whereas in Curculionidae and Brentidae (s. lato), the contour is more or less produced caudally in an arc.

May (1994) noticed the importance of "the postoccipital condyles" on the systematics for the first time and employed its presence or absence in the first couplete of the key to the families. Marvaldi (1997) coded this structure into three states, namely (0) simple, (1) with condyle or sclerotized flange on each side, and (2) with postoccipital condyles inconspicuous and represented by thickened ridge along margin, and (2) was recognized in Cossoninae and Scolytinae in her matrix. But the larval head of such Cossoninae as Kojimazo (=Heterarthrus) and Sphaerocorynes (fig. 121) is of the typical Curculionidae, and the larvae of Scolytidae and Platypodidae have not any trace of the cervical plates on the cervix (figs. 113-117) except for the postoccipital ridge on the head. Thus, this structure should be coded into two states, present or absent. The cervix must be examined by pulling out the head from the prothorax after treating the larvae by $\mathrm{KOH}$ solution and before removing the head from the prothorax.

Another sclerotized structure is present at the dorsal part of the cervix behind the caudal margin of the postocciput, which is inflected and often bears a pair of sclerites (figs. 114-117, 123-124). The muscles are not attached to it, but to the postocciptial ridge or condyles at both sides of the caudal end of the coronal suture. Thus, this is of the structure of the cervix, but our observation is insufficient to discuss further.

\section{Phylogemetic amalysis}

On the structures of the weevil head observed in this paper in the adults, characters used for the phylogenetic analyses are listed below. The structure is defined according to its hypothesized plesiomorphic state $(0)$ and apomorphic state(s) $(1,2, \cdot \cdot)$ on the basis of polarity. Phylogenetic reconstruction was accomplished by the computer-aided reconstruction using PAUP* version 4 (Swofford, 2002). A hypothetical ancestor with all characters coded plesiomorphic, was used for analysis. Branch and bound search 
algorithm was used to guarantee discovery of the shortest trees. Character mapping was done using MacClade 4 (Maddison \& Maddison, 2001).

\section{Characters of head and character states}

1. Pleurostomal sinus: (0) deep, U-shaped; (1) shallow or indistinct.

2. Pleurostomal space in the sinus: (0) membranous; (1) covered by the laterobasal lobe of mandible.

3. Postcoila: (0) C-shaped with an opening on internal to anterointernal face, and shallow fossa; (1) hemispherical deep fossa with C-shaped to ringed rim; (2) shallow fossa on anterior face of hypostoma.

4. Hypostomal process: (0) rounded at apex; (1) produced and triangular or sharp at apex; (2) absent.

5. Hypopharyngeal bracon: (0) absent; (1) narrow, bridge-like; (2) broad, wall-like.

6. Labrum: (0) present; (1) obliterated.

7. Mandibles at laterobasal corner: (0) simple and not prolonged into the condyle or lobe; (1) prolonged into a semiglobular condyle; (2) inflected between the pre- and postcoilae on the exterior surface, and lamellar exteriorly covering the joint of abductor tendon to mandible.

8. Mandibles move: (0) almost in a horizontal plane; (1) more or less oblique upwards.

9. Mandibles on outer surface: (0) with sulci and characteristic setae; (1) without sulci and a few setae.

10. Mandibles with lateral depression at the base: (0) simply convex or flat; (1) with lateral depression for receiving a prominence of the pleurostoma.

11. Mandibles with apical and ventral teeth: (0) apical tooth at the apex; (1) ventral tooth shifted to the visible apex.

12. Mandibles with ventral cutting edge: $(0)$ sharp and almost parallel to the dorsal cutting edge, consequently the inner concavity between both edges faced inwards; (1) shifted to side margin and obsolete at base, consequently the inner concavity becoming shallow surface and faced inner-ventrad.

13. Mandibles with mola: (0) present; (1) absent.

14. Maxillae with palpi: (0) long and four-segmented; (1) short, rigid and threesegmented.

15. Maxillae move: (0) almost in a horizontal plane; (1) more or less obliquely upwards; (2) almost vertical.

16. Maxillae with galea and lacinia: (0) separated as distinct lobes; (1) fused into mala. 17. Maxillae with arrangement of sensory pores on ultimate segment of palpi: (0) parallel; (1) radiating. 
18: Prementum: (0) in front of postmentum and well visible ventrally; (1) deeply retracted into oral cavity and invisible ventrally.

19: Prementum with ligula: (0) present, produced anteriorly in front of labial palpi; (1) absent or not produced, but ental part developed into membranous ligula at most.

20: Labial palpi: (0) on ventral surface of prementum close to side margins; (1) on apical margin of prementum and visible ventrally; (2) ental surface of prementum and invisible ventrally; (3) in socket on apicoental surface of prementum.

21: Postmentum: (0) wider than prementum; (1) almost as wide as or narrower than prementum.

22: Strengthening structures of rostrum at the bottom of hypopharyngeal sinus: (0) not developed; (1) well developed.

23: Gular sutures: (0) paired and long; (1) paired and short; (2) paired and very short; (3) partly fused and Y-shaped; (4) completely fused and linear.

24: Tentorium with posterior tentorial bridges: (0) paired; (1) partly fused; (2) completely fused and visibly triangular.

25: Tentorium with posterior tentorial bridges at their apical margin: (0) widely distant from paracoila; (2) close to paracoila; (3) meet the sheet-like extension of the hypostoma from paracoila.

26: Antennae: (0) orthocerous; (1) geniculate.

Data matrix is compiled from the mentioned characters and character states in table 1 , and the reconstructed relative relationships of the principal taxa are represented in figs. 126 and 127.

\section{Discussion}

Our result obtained (figs. 126, 127) is in discord with those of Kuschel (1995), Marvaldi \& Morrone (2000), and Marvaldi et al. (2002) in the systematic positions of the families Scolytidae and Platypodidae, which are recognized not as the subfamilies of Curculionidae but as independent families from the offshoots between the primitive and advanced families. This discordance must be caused on the reason that our adoption of many new information from the head structures for the phylogenetic analyses.

From the above mentioned facts, following modification of the tentorium and gula can be inferred that the ancestor of Curculionoidea may have the short and straight rostrum, with complete and relatively larger tentorium, and two ways of differentiation from this condition are apparent in accordance with the development of slender rostrum and increase of the adductor and abductor muscles of the mandibles originating from the head cranium. The first way must be the shortening of the gula and tentorium as seen in the primitive families, and the other way is the coalescence of the gular sutures 
and diminishing the gula so as to form the tentorium triangular when viewed internally (fig. 93). By these modifications, the cranium can afford broader space for the muscle insertions and the functional space for the tendons at the anterior part. However, the tentorium of Scolytidae and Platypodidae are quite different from these conditions and may have specially modified from the ancestral features as discussed in the following lines.

The families Scolytidae and Platypodidae share the following characters: pleurostomal sinus weak, postcoila shallow and simple lying on the anterior margin of the hypostoma for receiving simple postartis, hypostomal process absent, mandible simple at laterobasal corner, mandible with lateral depression for receiving the prominence of pleurostomal margin, gular sutures Y-shaped in general or exceptionally paired in the primitive condition, posterior tentorial arms broadly continued to the divaricated part of gular suture (pregular sutures of some authors), and the strengthening sclerotization undeveloped at and behind paracoila. The relatively broad tentorium, partly or wholly separated gular sutures, short distance in front of the gula, primitive conditions of the mandibles, undeveloped stengthening sclerotization of the paracoila, and absence of the apodeme for supporting the mandibular tendons may suggest the origin of these families from an ancestor of a short and straight rostrum as in the extant state, not from the ancestor having modified head and mouthparts by the prolongation of rostrum, and they are very different from those of Cossoninae regardless of the external similarity, which include such alike weevils as Stenoscelis and Pachyops to some Scolytidae. Their great difference is thus apparent when the mouth-parts and the rostrum are observed from the underside and inside, and Xenocnema can not be regarded as the bridge between Cossoninae and Scolytidae (Morimoto, 1973) as opposed to Crowson (1967) and Kuschel $(1966,1995)$, though the other genera of the tribe Araucariini have not yet been examined.

The family Platypodidae is characteristic in the tentorium and maxilla of the head structures as mentioned above. Though the detail is unknown in the primitive genera of Platypodidae, Protoplatypus may possibly have the same characters in the head structures on our assumption from the photograph in Kuschel et al. (2000; p. 791, fig. 117), which clearly showed the pregular suture extending anteriorly as far as the bottom of hypostomal sinus on each side.

The families Nanophyidae, Apionidae, Brentidae, Brachyceridae, Dryophthoridae and Curculionidae constitute a higher group having the similar head structures in the following features: labrum absent, pleurostomal sinus deep, postcoila deep and Cshaped or circular lying behind the anterior margin of hypostoma for receiving globular postartis, hypostomal process prominent, mandible with laterobasal lamella covering the base of abductor tendon, mandible without lateral depression for receiving the 
prominence of the pleurostomal margin, gular sutures completely coalescent and linear, posterior tentorial arms distant from hypostoma, and the strengthening sclerotization well developed at and behind paracoila.

On these facts, we approve the treatment of Scolytidae and Platypodidae as independent families from Curculionidae as did by Wood $(1973,1986)$ and are placed them in the position between the primitive and advanced families (figs. 126, 127). Although the larvae of Scolytidae have not been distinguished from Curculionidae (Böving \& Craighead, 1931; Gardner, 1934; Viedma, 1963; Lekander, 1968; May, 1993, 1994), and "present an enigma" (Wood, 1986), the absence of the cervical plates in Scolytidae and Platypodidae as in the primitive families must be a new fact clearly supporting our present conclusion from the larval structures.

\section{References}

Alonso-Zarazara, M. A. \& C. H. C. Lyal, 1999. A world catalogue of families and genera of Curculionoidea (Insecta: Coleoptera) (Excepting Scolytidae and Platypodidae). 315 pp., Entomopraxis, Barcelona, Spain.

Anderson, R. S., 1995. An evolutionary perspective on diversity in Curculionoidea. Mem. ent. Soc. Wash., 14: 103-114.

Anderson, W. H., 1947. A terminology for the anatomical characters useful in the taxonomy of weevil larvae. Proc. ent. Soc. Wash., 49: 123-132.

Aslam, N. A., 1961. An assessment of some internal characters in the higher classification of the Curculionidae s. l. (Coleoptera). Trans. r. ent. Soc. Lond., 113: 417-489.

Bitsch, J., 1966. L'évolution des structures céphaliques chez les larves de Coléoptères. Ann. Soc. ent. Fr., (N. S.), 11: 255-324.

Blatchley, W. S. \& C. W. Leng, 1916. Rhynchophora or weevils of North Eastern America. 682 pp., Indianapolis.

Böving, A. G. \& F. C. Craighead, 1931. An illustrated synopsis of the principal larval forms of the order Coleoptera. Ent. Amer., 11(n.s.), 86 pp. +125 pls.

Brack-Egg, A., 1973. Der Kopf von Rhynchites aurautus Scop. (Curculionidae) - Eine konstruktionsmorphologische Untersuchung mit einem Beitrag zum Brutfürsogeverhalten. Zool. Jahrb., (Abt. Anat.), 91: 500-545.

Browne, F. G., 1972. Larvae of the principal old world genera of the Platypodinae (Coleoptera: Platypodidae). Trans. r. ent. Soc. Lond., 124(2): 167-190.

Burrini, A. G., L. Magnano, A. R. Magnano, C. Scala \& B. Baccetti, 1988. Spermatozoa and phylogeny of Curculionoidea (Coleoptera). Int. J. Inse \& Embryol., 17: 1-50. 
Calder, A. A., 1989. The alimentary canal and nervous system of Curculionoidea (Coleoptera): gross morphology and systematic significance. J. nat. Hist., 23: 1205-1265.

Calder, A. A., 1990. Gross morphology of the soft parts of the male and female reproductive systems of Curculionoidea (Coleoptera). J. nat. Hist., 24: 453-505.

Cook, E. F., 1943. The head of some Coleoptera. Microentomology, 8: 25-40.

Crowson, R. A., 1955 (reprint 1967). The natural classification of the families of Coleoptera, 187 pp. + addenda et corrigenda. Classey, Middlesex, U. K.

Crowson, R. A., 1984. On the systematic position of Bruchela Dejean (Urodon auct.) (Coleoptera). Coleopt. Bull., 38: 91-93.

Crowson, R. A., 1985. The systematic position of Nemonyx Redtenbacher (Coleoptera: Curculionoidea: Nemonychidae). Ent. Gener., 11: 57-58.

Crowson, R. A., 1986. On the systematic position of Allocoryninae (Coleoptera: Allocorynidae). Coleopt. Bull., 40: 243-244.B

Denis, J-R. \& J. Bitsch, 1973. Structure céphalique dans les ordres des insectes. In Grassé (ed.), Traité de Zoologie, VIII, Fasc. 1: 101-593.

Dennell, R., 1942. The structure and function of the mouth-parts, rostrum and foregut of the weevil Calandra granaria L. Phil. Trans. r. Soc. Edinb., B, No. 581, 231: 247-291.

Dönges, J., 1954. Der Kopf von Cionus scrophulariae L. (Curculionidae). Zool. Jahrb. (Abt. Anat.), 74: 1-76.

DuPorte, E. M., 1957. The comparative morphology of the insect head. Ann. Rev. Ent., 2: 55-70.

DuPorte, E. M., 1960. Evolution of cranial structure in adult Coleoptera. Can. J. Zool., 38: 655-675.

Evans, M. E. G., 1961. The muscular and reproductive systems of Atomaria ruficornis (Marsham) (Coleoptera, Cryptophagidae). Trans. r. Soc. Edinb., 64(14): 297-399.

Farrell, B. D., 1998. "Inordinate fondness" explained: Why are there so many beetles. Science, (281): 555-559.

Ferris, G. F., 1942. Some observations on the head of insects. Microentomology, 7: 25-62.

Ferris, G. F., 1943. The basic materials of the insect cranium. Microentomology, 8 : 8-24.

Ferris, G., 1947. The contradiction of the insect. head. Microentomology, 12: 60-64.

Gardner, J. C. M., 1934. Immature stages of Indian Coleoptera (15) (Scolytidae). Ind. For. Rec., 20 (part 8): 1-17, 2 pls.

Hopkins, A. D., 1911. I. Contributions toward a monograph of the bark-weevils of the genus Pissodes. Technical Ser., 20, Part 1. $\mathrm{X}+68$ pp., I-XXII pls., U. S. D. A., 
Bureau of Ent.

Imms, A. D., 1925 (10th ed.1977). A general textbook of entomology, 10th ed., viii +1354 pp. in 2 vols., revised by O. W. Richards \& R. G. Davies. Chapman \& Hall, London.

Kasap, H. \& R. A. Crowson, 1977. A comparative study of the internal anatomy and abdominal structures of Curculionoidea.' Hacettepe Bull. nat. Sci. Engine., Ankara, 6: 35-86.

Korolyov, S. G., 1989. Morphology of the larvae of beetles of the genus Platypus Herbst (Coleoptera, Platypodidae) in connection with peculiarities of their ecology. Rev. d'Ent. URSS, 68: 353-360. (In Russian)

Kukalova-Peck, J., 1991. Fossil history and the evolution of hexapod structures. In The Insects of Australia, I: 141-179, Melbourne Univ. Press., Carlton.

Kuschel, G., 1966. A Cossonine genus with bark-beetle habits, with remarks on relationships and biogeography (Coleoptera Curculionidae). New Zealand J. Sci., 9: 3-29.

Kuschel, G. 1989. The Nearctic Nemonychidae (Coleoptera: Curculionoidea). Ent. scand., 20: 121-171.

Kuschel, G. 1993. The Palaearctic Nemonychidae (Coleoptera: Curculionoidea). Ann. Soc. ent. Fr., (N. S.), 29: 23-46.

Kuschel, G., 1995. A phylogenetic classification of Curculionoidea to families and subfamilies. Mem. ent. Soc. Wash., 14: 4-33.

Kuschel, G., R. A. B. Leschen \& E. C. Zimmerman, 2000. Platypodidae under scrutiny. Invertebrate Taxonomy, 14: 771-805.

Lekander, B., 1968. Scandinavian bark beetle larvae, descriptions and classification. Research Notes, Nr. 4: 186 pp., Inst. Skogszool., Dept. Forest Zool., Royal College of Forestry, Stockholm.

Lyal, C. H. C., 1995. The ventral structures of the weevil head (Coleoptera: Curculionoidea). Mem. ent. Soc. Wash., 14: 35-51.

Maddison, D.R. \& W.P. Maddison, 2001. MacClade, 4: Analysis of Phylogeny and Character Evolution. Version 4.03. Sinauer Associates, Sunderland, Massachusetts. Marshall, G. A. K., 1916. The fauna of British India, including Ceylon and Burma. Coleoptera, Rhynchophora, Curculionidae Part 1, xv+367 pp., Taylor and Francis, London.

Marvaldi, A. E., 1997. Higher level phylogeny of Curculionidae (Coleoptera: Curculionoidea) based mainly on larval characters, with special reference to broad-nosed weevils. Cladistics, 13: 285-312.

Marvaldi, A. E. \& J. J. Morrone, 2000. Phylogenetic systematics of weevils (Coleoptera: Curculionoidea): a reappraisal based on larval and adult morphology. 
Insect Syst. Evol., 31: 43-58.

Marvaldi, A. E., A. S. Sequeira, C. W. O’Brien \& B. D. Farrell, 2002. Molecular and morphological phylogenetics of weevils (Coleoptera, Curculionoidea): Do niche shifts accompany diversification ? Syst. Biol., 51(5): 761-785.

Matsuda, R., 1965. Morpholgy and evolution of the insect head. Mem. Amer. ent. Inst., (4): $334 \mathrm{pp}$.

May, B. M., 1993. Larvae of Curculionoidea (Insecta: Coleoptera): A systematic overview. Fauna of New Zealand, No. 29. Manaaki Whenuta Press, Lincoln, New Zealand.

May, B. M., 1994. An introduction to the immature stages of Australian Curculionoidea. In Zimmerman (ed.), Australian Weevils, II: 365-721, CSIRO, Australia.

McClenahan, E. M., 1904. The development of the rostrum in rhynchophorous Coleoptera. Psyche, 11: 89-102, 4 pls.

Morimoto, K., 1962. Comparative morphology and phylogeny of the superfamily Curculionoidea of Japan. J. Fac. Agr., Kyushu Univ., 11(4): 331-373.

Morimoto, K., 1962. Key to families, subfamilies, tribes and genera of the superfamily Curculionoidea of Japan excluding Scolytidae, Platypodidae and Cossoninae. $J$. Fac. Agr., Kyushu Univ., 12(1): 21-66.

Morimoto, K., 1973. On the genera of Oriental Cossoninae (Coleoptera: Curculionidae). Bull. Gov. Forest exp. Sta., Tokyo, (257): 81-100, 16 pls.

Morimoto, K., 1976. Notes on the family characters of Apionidae and Brentidae, with a key to the related families. Konty $\hat{u}, 44: 469-476$.

Morimoto, K., 1981. Functional morphology and phylogeny of the superfamily Curculionoidea (Coleoptera). Part 1. The mouth parts. Akitu (N. S.), 34: 1-10.

Morimoto, K., 1986. Phylogeny and classification. In Morimoto \& Hayashi (eds.), The Coleoptera of Japan in Color, I: 142- 201. Hoikusha, Osaka. (In Japanese)

Morimoto, K. \& H. Kojima, 1994. On the systematic position of the genus Euphyllobiomorphus: an adelognathous weevil with cylindrical rostrum (Coleoptera, Curculionidae). Esakia, (34): 131-146.

Oberprieler, R., 2000. The larvae of the weevil tribe Eurhynchini and the phylogeny of the Brentidae (Coleoptera: Curculionoidea. Invertebrate Taxonomy, 14: 753-770.

Rempel, J. G., 1975. The evolution of the insect head: The endless dispute. Quaest. Ent., 11: 7-25.

Sanborne, M., 1981. Biology of Ithycerus noveboracensis (Forster) (Coleoptera) and weevil phylogeny. Evolut. Monogr., 4: 1-80.

Snodgrass, R. E., 1935. Principles of insect morphology. ix+667, McGraw-Hill, New York and London.

Snodgrass, R. E., 1947. The insect cranium and the "epicranial suture". Smithson. 
misc. Coll., 107: 11-52.

Snodgrass, R. E., 1960. Facts and theories concerning the insect head. Smithson. misc. Coll., 142 (1): 1-61.

Stickney, F. S., 1923. The head-capsule of Coleoptera. Illinois biol. Monogr., 8(1): 104 pp., 24 pls.

Swofford, D. L., 2002, PAUP*, version 4, Sinauer Associates, Massachusetts.

Thompson, R. T., 1992. Observations on the morphology and classification of weevils (Coleoptera: Curculionoidea) with a key to major groups. J. nat. Hist., 216: 835891.

Ting, P. C., 1933 Feeding mechanisms of weevils, their function and relationship to classification. Calif. Dept. Agr., Month. Bull., 22: 161-165.

Ting, P. C., 1936. The mouth parts of the Coleopterous group Rhynchophora. Microentomology, 1: 93-114.

Viedma, M. G. de, 1963. Contribución al conocimiento de las larvas de Curculionidae lignivoros europeos. Eos, 39: 257-277.

Wanat, M., 2002. Genera of Australo-Pacific Rhadinocybinae and Myrmacicelinae, with biogeography of the Apionidae (Coleoptera: Curculionoidea) and phylogeny of the Brentidae (s. lato). 432 pp., Mantis, Olsztyn, Poland.

Weber, H., 1952. Morphologie, Histologie und Entwicklungsgeschichte der Articulaten. Fortschr. Zool., 9: 18-231.

Williams, I., 1938. The comparative morphology of the mouthparts of the order Coleoptera treated from the standpoint of phylogeny. J. New York ent. Soc., 46: 245-288, pls. XIII-XXIII.

Wink, M., Z. Mikes \& J. Rheinheimer, 1997. Phylogeneric relationship in weevils (Coleoptera: Curculionoidea) inferred from nucleotide sequences of mitochondrial 16S rDNA. Naturwissenschaften, 84: 318-321.

Wood, S. L., 1973. On the taxonomic status of Platypodidae and Scolytidae (Coleoptera). Great Basin Naturalist, 33: 77-90.

Wood, S. L., 1986. A reclassification of the genera of Scolytidae (Coleoptera). Great Basin Naturalist Memoirs, 10: 1-126.

Wood, S. L., 1993. Revision of the genera of Platypodidae (Coleoptera). Great Basin Naturalist, 53(3): 259-281.

Zimmerman, E. C., 1993, 1994. Australian weevils (Coleoptera: Curculionoidea). Vol. I: xxxii+741 pp.(1994a); Vol. II: x+755 pp.(1994b); Vol. III: viii+854 pp. (1993). CSIRO, Australia. 


\section{Appendix}

Species examined are listed mostly after Alonso-Zarazaga \& Lyal, 1999.

1. Adults.

Nemonychidae: Cimberis attelaboides, Rhinorhynchus rufulus.

Anthribidae: Anthribus niveovariegatus, Opanthribus tessellatus, Apolecta lewisii, Basitropis nitidicutis, Habrissus longipes; Euparius oculatus, Japanthribus kusuii, Illis anna, Ozotomerus amamianus, Exillis japonicola, Platystomos sellatus, Asemorhinus nebulosus, Tropideres naevulus, Sphinctotropis laxus, Autotropis distinguenda; Araecerus coffeae; Bruchela rufipes.

Belidae: Rhinotia semipunctatus, Rhinotia haemoptera, Dicordylus marmoratus.

Oxycorynidae: Aralius wollastoni, Proterhinus sp.; Metrioxena sumatrana.

Rhynchitidae: Cyllorhynchites ursulus, Involvulus pilosus, Involvulus singularis, Neocoenorrhinus assimilis, Rhynchites heros, Aderorhinus crioceroides, Eugnamptus amurensis; Auletobius planifrons, Auletobius uniformis, Aspidobyctiscus lacunipennis, Byctiscus fausti, Byctiscus puberulus regalis, Chokkirius truncatus, Deporaus unicolor, Chonostropheus chujoi.

Attelabidae: Attelabus christophi, Himatolabus cupreus, Henicolabus lewisii, Euops splendidus, Euops punctatostriatus; Apoderus jekelii, Apoderus erythrogaster, Paroplapoderus pardalis, Phymatapoderus latipennis, Cycnotrachelus roelofsi, Paracentrocorynus nigricollis, Paratrachelophorus longicornis.

Ithyceridae: Ithycerus noveboracensis.

Brentidae: Baryrhynchus poweri, Pseudorychodes insignis; Antliarhinus verdcowrti; Cylas formicarius; Cerobates formosanus, Trachelizus japonicus.

Apionidae: Perapion violaceum, Cybebus rufipennis, Eutrichapion viciae.

Nanophyidae: Nanophyes marmoratus, Nanophyes pallipes.

Brachyceridae: Brachycerus algirus; Desmidophorus crassus, Desmidophorus cummingi.

Dryophthoridae: Dryophthorus konishii; Cryptoderma fortunei; Sipalinus gigas; Rhynchophorus ferrugineus, Otidognathus jansoni, Diocalandra sasa, Sitophilus zeamais, Aplotes roelofsi, Rhabdoscelus obscurus, Dryophthoroides sulcatus.

Erirhinidae: Echinocnemus squameus, Notaris oryzae; Lissorhoptrus oryzophilus, Stenopelmus rufimanus, Tanysphyrus brevipennis, Tanysphyrus major; Tadius erirhinoides.

Curculionidae

Curculioninae: Archarius pictus, Curculio convexus, Curculio dentipes, Curculio sikkimensis; Acalyptus carpini; Anthonomus bisignatus, Bradybatus sharpi; Cionus helleri, Stereonychus thoracicus; Derelomus uenoi; Dorytomus maculipennis; Gymnetron miyoshii; Isochnus sorbi, Tachyerges stigma, Orchestes sanguinipes, 
Rhamphus pulicarius; Rhynchaenus pacificus; Ixalma hilleri; Tychius ovalis.

Bagoinae: Bagous bipunctatus.

Baridinae: Baris orientalis, Moreobaris deplanata, Anthinobaris dipilota, Pellobaris melancholica; Phrissoderes rufitarsis.

Ceutorhynchinae: Ceutorhynchus diffusus, Wagnerinus ibukianus, Hyprus bertrandi, Mecysmoderes fulvus, Rhinoncus cribricollis, Homorosoma asperum.

Conoderinae: Metialma cordata, Lobotrachelus minor, Mecopomorphus griseus, Mecopus bispinosus, Telephae konoi.

Cossoninae: Cossonus formosanus, Kojimazo lewisii, Stenoscelis gracilitarsis, Macrorhyncolus crassiusculus, Pachyops sp. (ex. Ogasawara Isls.).

Cryptorhynchinae: Cryptorhynchus lapathi, Shirahoshizo rufescens, Sclerolips maculicollis, Simulatacalles simulator, Camptorhinus dorsalis, Eutyrhinus yaeyamanus, Gasterocercus longipes, Mechistocerus nipponicus, Rhadinomerus maebarai, Rhadinomerus unmon.

Cyclominae: Isonycholips gotoi, Listroderes costirostris.

Entiminae: Dactylotus japonicus, Arrhaphogaster pilosa, Isopterus kotoensis, Neasphalmus okinawanus, Hypotactus papillatus, Philicoptus waltoni, Catapionus viridimetallicus, Anosimus decoratus, Cyrtepisomus castaneus, Myosides seriehispidus, Oedophrys hilleri, Myllocerus griseus, Dermatoxenus caesicollis, Elytrurus expans, Episomus turritus, Rhinoscapha funebris, Otiorhynchus ovatus, Ottistira sp. (ex. New Britain), Metapocyrtus bituberosus, Pachyrhynchus infernalis, Phyllobius rotundicollis, Phyllobius picipes, Polydrusus ruficornis, Scythropus ornatus, Eugnathus distinctus, Sitona japonicus, Chlorophanus grandis, Scepticus griseus, Sympiezomia lewisii, Amystax fasciatus, Trachyphloeosoma setosum, Byrsopages kiso.

Hyperinae: Hypera basalis, Hypera postica.

Lixinae: Larinus ovalis, Lixus impressiventris, Lixus acutipennis, Cleonus japonicus.

Mesoptiliinae: Carcilia strigicollis.

Molytinae: Acicnemis albofasciata, Trachodes murakamii, Niphades variegatus, Catagmatus japonicus, Aclees hirayamai, Hylobius roelofsi, Pimelocerus elongatus, Ectatorhinus adamsii, Colobodes konoi, Deretiosus angulicollis, Lepyrus japonicus, Meres flavosignatus, Ornatalcides trifidus, Edaphotrypetes ovipennis, Pissodes nitidus.

Scolytidae: Hylurgops interstitialis, Ips typographus, Xyleborus brevis, Xyleborus validus, Xylosandrus germanus, Scolytoplatypus tycon, Scolytoplatypus mikado.

Platypodidae: Crossotarsus nipponicus, Platypus lewisi, Platypus modestus. 


\section{Larvae}

Anthribidae: Euparius oculatus, Phloeobius stenus, Exechsops leucopis, Rhaphitropis guttifer, Autotropis distinguenda.

Rhynchitidae: Cyllorhynchites ursulus, Involvulus pilosus, Rhynchites heros, Auletobius uniformis, Aspidobyctiscus lacunipennis, Byctiscus puberulus regalis, Deporaus unicolor.

Attelabidae: Henicolabus lewisii, Euops splendidus, Apoderus jekelii, Apoderus erythrogaster, Paroplapoderus pardalis, Phymatapoderus latipennis, Cycnotrachelus roelofsi, Paratrachelophorus longicornis.

Brentidae: Cylas formicarius.

Apionidae: Perapion violaceum.

Nanophyidae: Nanophyes pallipes.

Brachyceridae: Desmidophorus crassus.

Dryophthoridae: Sipalinus gigas, Rhynchophorus ferrugineus, Rhabdoscelus similis, Sphenophorus venatus vestitus, Sitophilus zeamais, Myocalandra exarata.

Erirhinidae: Echinocnemus squameus, Lissorhoptrus oryzophilus.

Curculionidae: Curculio dentipes, Cionus helleri, Derelomus uenoi, Dorytomus urakoae, Baris orientalis, Ceutorhynchus alboscutellatus, Kojimazo lewisi, Sphaerocorynes sulcirostre, Phylloplatypus pandani, Shirahoshizo rufescens, Anthonomus bisignifer, Otiorhynchus sulcatus, Eugnathus distinctus, Pachyrhynchus infernalis, Episomus mundus, Scepticus griseus, Hypera basalis, Hypera postica, Larinus ovalis, Lixus impressiventris.

Platypodidae: Platypus quercivorus.

Scolytidae: Scolytus japonicus, Tomicus piniperda, Phloeosinus perlatus, Cryphalus fulvus. 


\section{Explanations of figures}

Figs. 1-8. Rostrum and head, lateral, showing pleurostomal sinus and mandibles. (After Morimoto, 1981, modified).

1: Basitropis nitidicutis. 2: Rhynchites heros. 3: Hylurgopus interstitialis.

4: Crossotarsus nipponicus. 5: Hylobius haroldi. 6: Phyllobius rotundicollis.

7: Stenoscelis gracilitarsis. 8: Rhynchophorus ferrugineus.

Figs. 9-17. Mouth parts, apical, diagrammatical. (After Morimoto, 1981, modified).

9: Anthribidae. 10: Attelabidae.11: Rhynchitidae. 12: Scolytidae. 13 : Platypodidae. 14: Curculionidae phanerognathi. 15: Entiminae. 16: Curculio. 17: Dryophthoridae.

Figs. 18-29. Postcoila of left hypostoma, dorsal.

18: Rhinotia semipunctata. 19: Auletobius planifrons. 20: Nanophyes pallipes.

21: Thalasselephas minor. 22: Hylurgopus interstitialis. 23: Euops splendidus.

24: Apoderus erythrogaster. 25: Araecerus coffeae. 26: Cybebus rufipennis.

27: Metapocyrtus bituberosus. 28: Baryrhynchus poweri (우). 29: Callipareius formosanus.

Figs. 30-37. Labrum and clypeus.

30, 31: Araecerus coffeae, inside or dorsal. 32: Apolecta lewisii, dorsa1. 33: Platystomos sellatus, dorsal. 34, 35: Japanthribus kusuii, dorsal and inside. 36: Bruchela rufipes, dorsal. 37: Rhinorhynchus rufulus.

Figs. 38-45. Mandible, diagrammatical, notice the laterobasal corner and postartis.

38: Rhinotia semipunctatus. 39: Deporaus unicolor. 40: Rhinorhynchus rufulus.

41: Euparius oculatus. 42: Platypus modestus. 43: Curculionidae phanerognathi. 44: Entiminae. 45: Curculio.

Figs. 46-55. Mandible.

46: Rhinorhynchus rufulus. 47: Rhinotia semipunctata. 48: Deporaus unicolor. 49: Apoderus erythrogaster. 50:Bruchela rufipes. 51: Euparius oculatus. 52: Pachyops sp. 53: Ips typographus. 54, 55: Crossotarsus nipponicus.

Figs. 56-63. Maxilla.

56, 57: Araecerus coffeae (56, inside showing hypopharyngeal bracon and position of maxilla, dotted). 58, 59: Rhinorhynchus rufulus (58, ventral, showing relative size of mouth parts). 60: Brachycerus algirus. 61: Sitona japonicus. 62: Episomus turritus. 63: Platypus lewisi.

Figs. 64-77. Labium.

64: Rhinorhynchus rufulus. 65: Japanthribus kusuii. 66: Illis anna. 67: Phialodes rufipennis. 68, 69: Henicolabus lewisii (69, palpus enlarged). 70: Auletobius uniformis. 71: Cyllorhynchites ursulus. 72: Cylas formicarius, inside. 
73: Cerobates formosanus. 74, 75: Diocalandra sasa (75, lateral). 76: Sipalinus gigas, lateral. 77: Ips typographus.

Figs.78-80. Head, dorsal aspect, showing important structures. Numbers in circle correspond to those of strengthening structures in text.

78: Euparius oculatus. 79: Apoderus jekelii. 80: Pachyops sp.

Figs 81-86. Hypostoma and labium, inside, showing strengthening structures.

81: Rhinotia semipunctata. 82: Aralius wollastoni. 83: Cybebus rufipennis.

84: Ithycerus noveboracensis. 85: Brachycerus algirus. 86: Sitona japonicus.

Figs. 87-92. Hypostoma, labium, strengthening structures and tentorium, inside.

87: Desmidophorus crassus. 88: Pissodes nitidus. 89: Cossonus formosanus.

90: Phyllobius rotundicollis. 91: Polydrusus ruficornis. 92: Metapocyrtus bituberculatus.

Figs. 93. Progressive differentiation of tentorium, a schema.

Figs. 94-103. Tentorium, inside.

94: Nakanea vicarina (Cerambycidae). 95: Rhinotia semipunctata. 96: Tropideres naevulus. 97: Rhinorhynchus rufulus. 98: Desmidophorus crassus. 99: Euops splendidus. 100: Curculio sikkimensis. 101: Apion sp. 102, 103: Paratrachelophorus longicornis (103, tentorium, lateral).

Figs.104-109. Tentorium of Scolytidae and Platypodidae.

104: Xyleborus validus. 105: Scolytoplatypus tycon. 106: Ips typographus. 107:

Platypus modestus. 108 : Platypus lewisi. 109: Crossotarsus nipponicus, female.

Figs.110-125. Larval head and cervix, showing cervical plates.

110: Araecerus coffeae. 111: Byctiscus puberulus. 112 : Cyllorhynchites urusulus.

113: Tomicus piniperda. 114, 115: Scolytus japonicus, ventral and lateral. 116, 117: Platypus quercivorus, ventral and lateral. 118: Cylas formicarius. 119: Baris orientalis. 120: Orchestes sanguinipes. 121: Sphaerocorynes sulcirostre. 122: Shirahoshizo rufescents. 123, 124: Rhabdoscelus similis. 125: Rhynchophorus ferrugineus, cervical plate.

Fig.126. One of 40 parsimonious trees.

Fig.127. Strict consensus of 40 trees. 


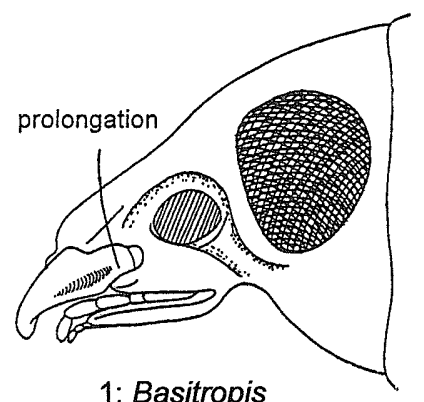

1: Basitropis

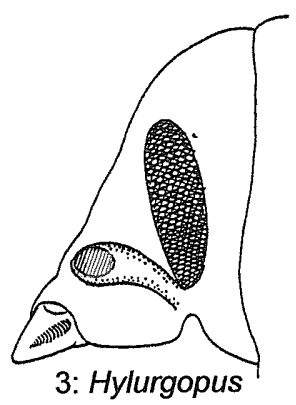

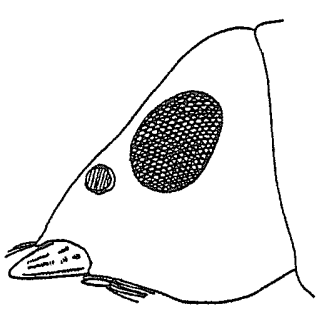

4: Crossotarsus

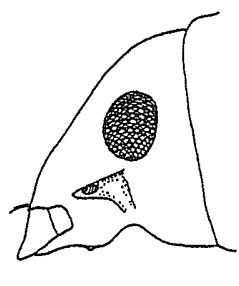

7: Stenoscelis

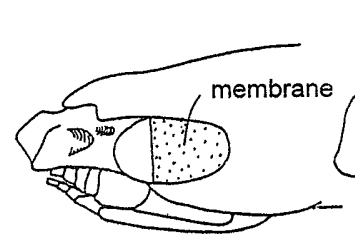

2: Rhynchites

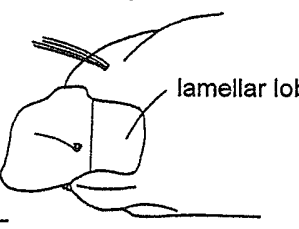

5: Hylobius

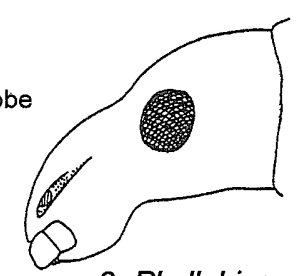

6: Phyllobius

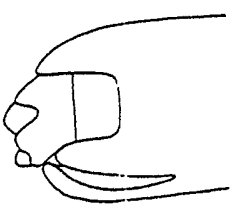

8: Rhynchophorus

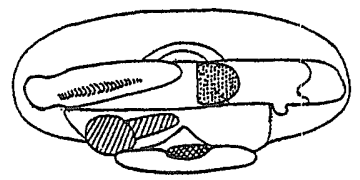

9: Anthribidae

lateral depression

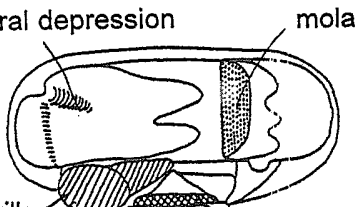

maxilla prementum

10: Attelabidae

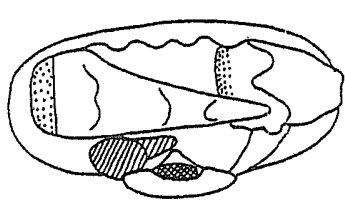

11: Rhynchitidae

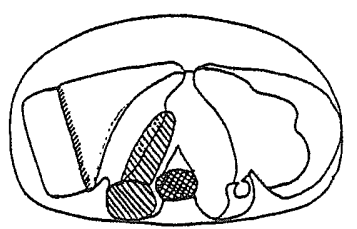

14: Curculionidae phanerognath

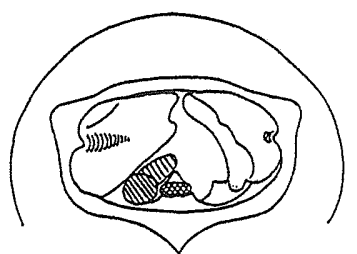

12: Scolytidae

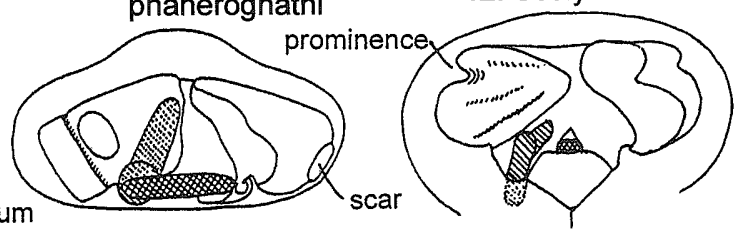

15: Entiminae

13: Platypodidae

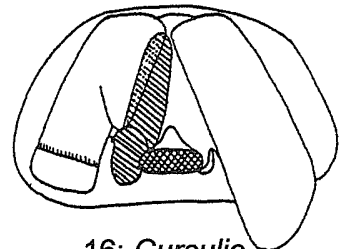

16: Curculio

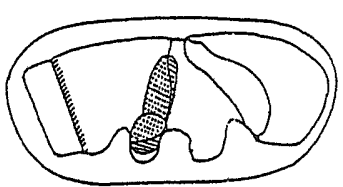

17: Dryophthoridae 


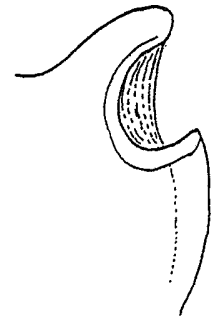

18: Rhinotia

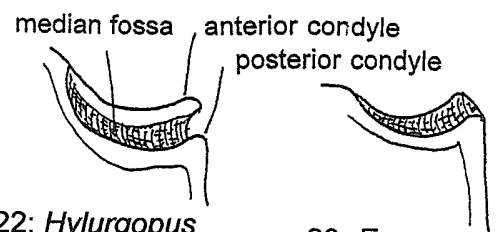

22: Hylurgopus

hypostomal

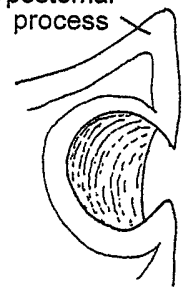

26: Cybebus

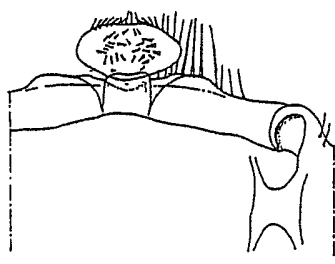

30: Araecerus

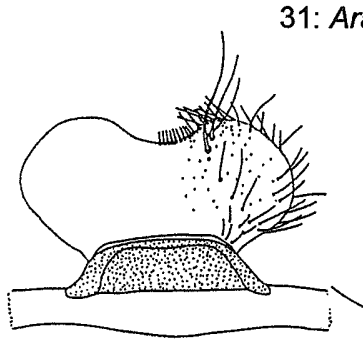

32: Apolecta

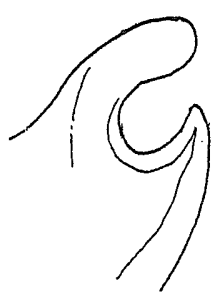

19: Auletobius

23: Euops

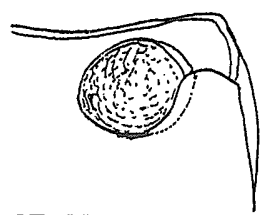

27: Metapocyrtus
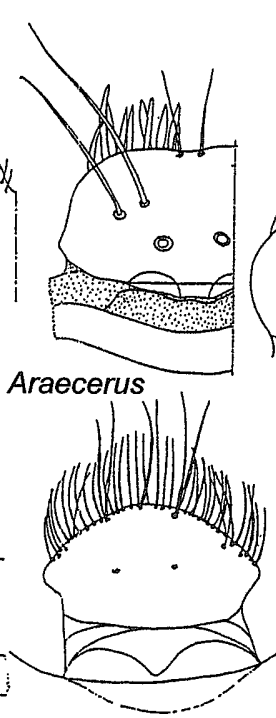

33: Platystomos

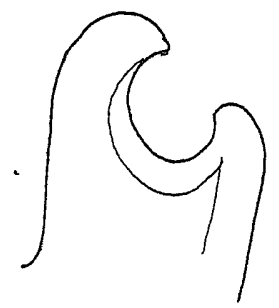

20: Nanophyes

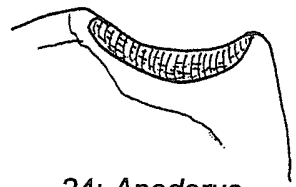

24: Apoderus

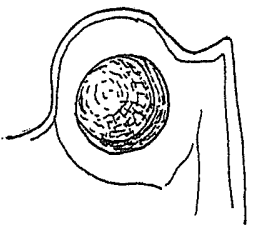

28: Baryrhynchus (우)

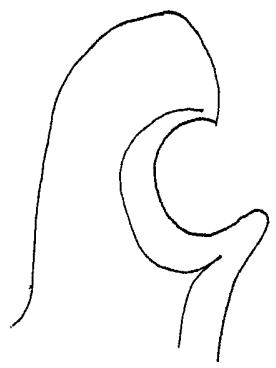

21: Thalasselephas

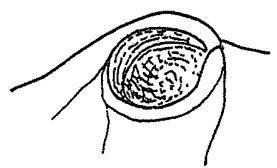

25: Araecerus

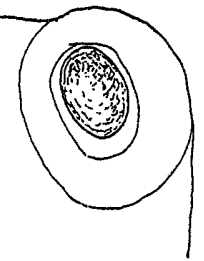

29: Callipareius

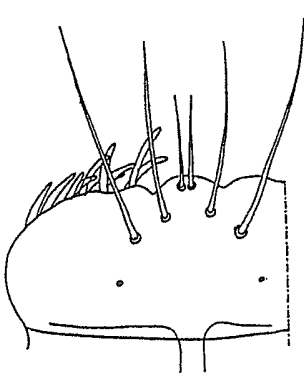

34: Japanthribus

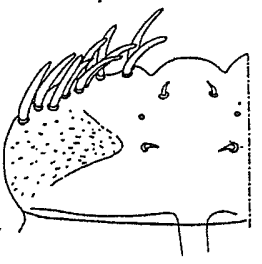

35: Japanthribus

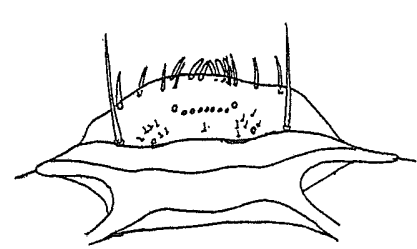

36: Bruchela

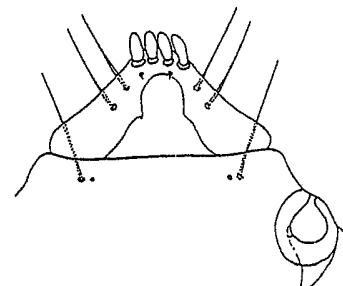

37: Rhinorhynchus 


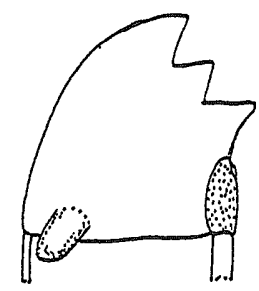

38: Rhinotia

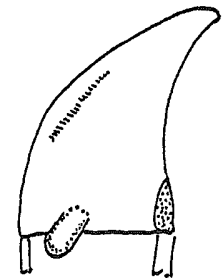

40: Rhinorhynchus

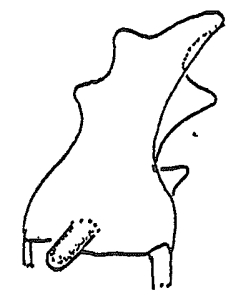

39: Deporaus

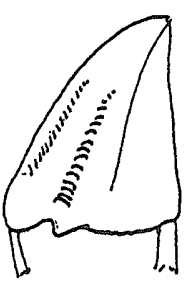

42: Platypus

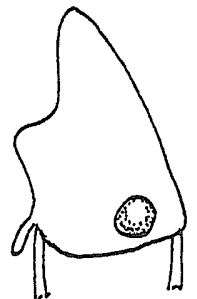

45: Curculio

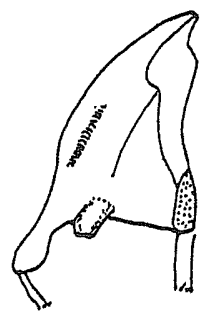

41: Euparius

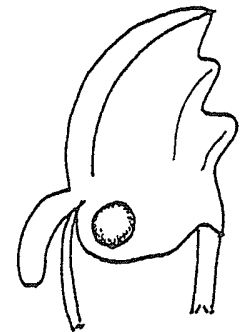

43: Curculionidae phanerognathi

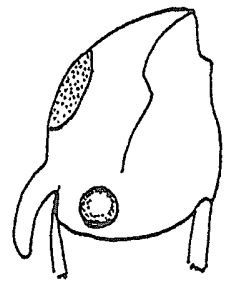

44: Entiminae

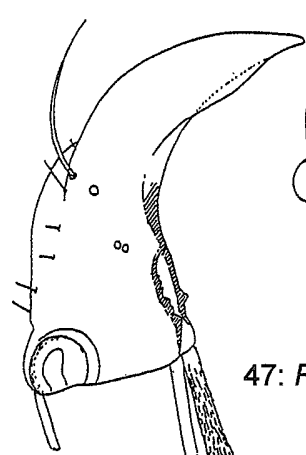

46: Rhinorhynchus

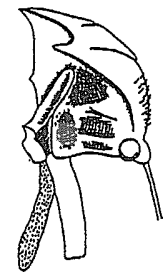

51: Euparius

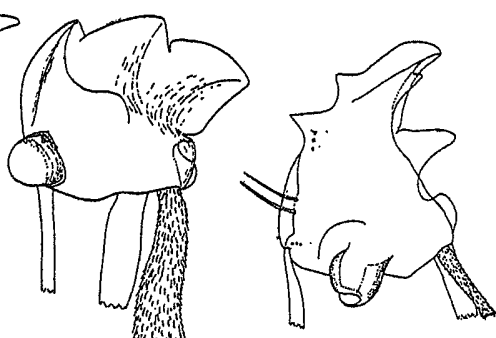

48: Deporaus

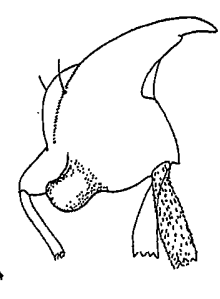

49: Apoderus

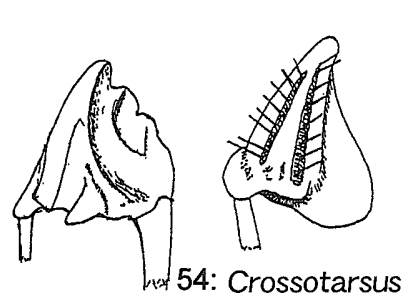

53: Ips

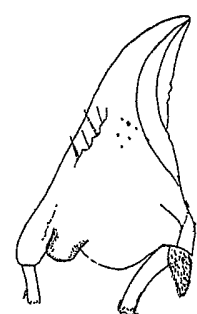

50: Bruchela
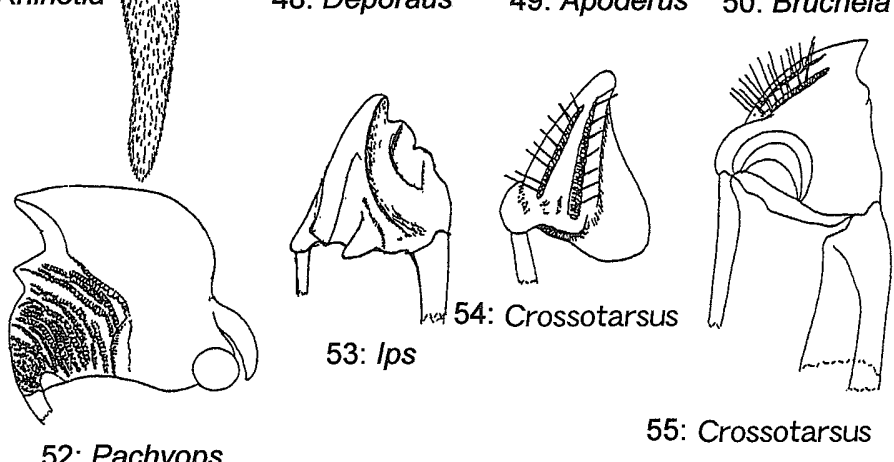

55: Crossotarsus 


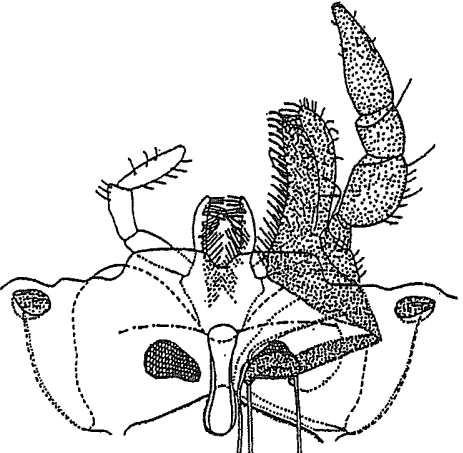

56: Araecerus

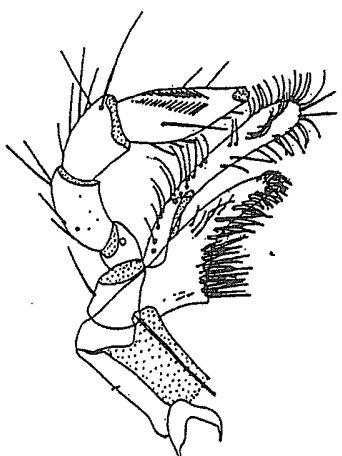

57: Araecerus

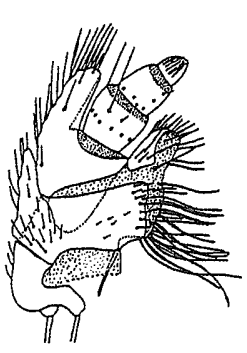

60: Brachycerus

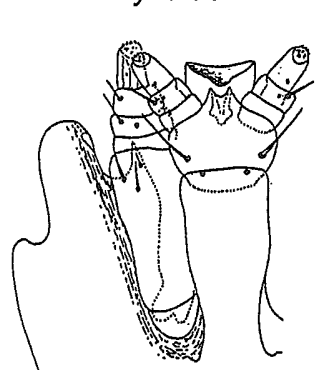

64: Rhinorhynchus
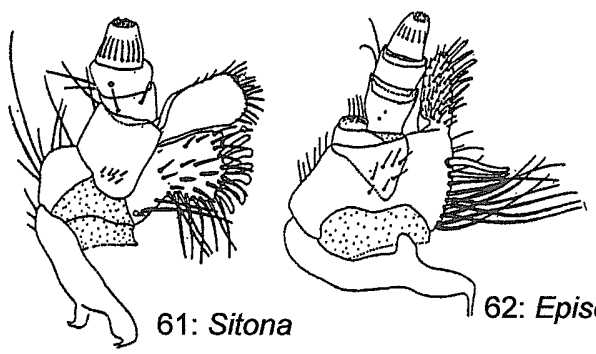

62: Episomus

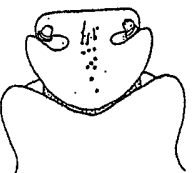

67: Phialodes

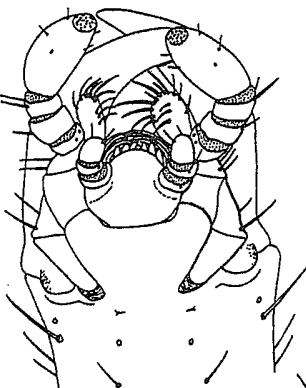

58, 59: Rhinorhynchus
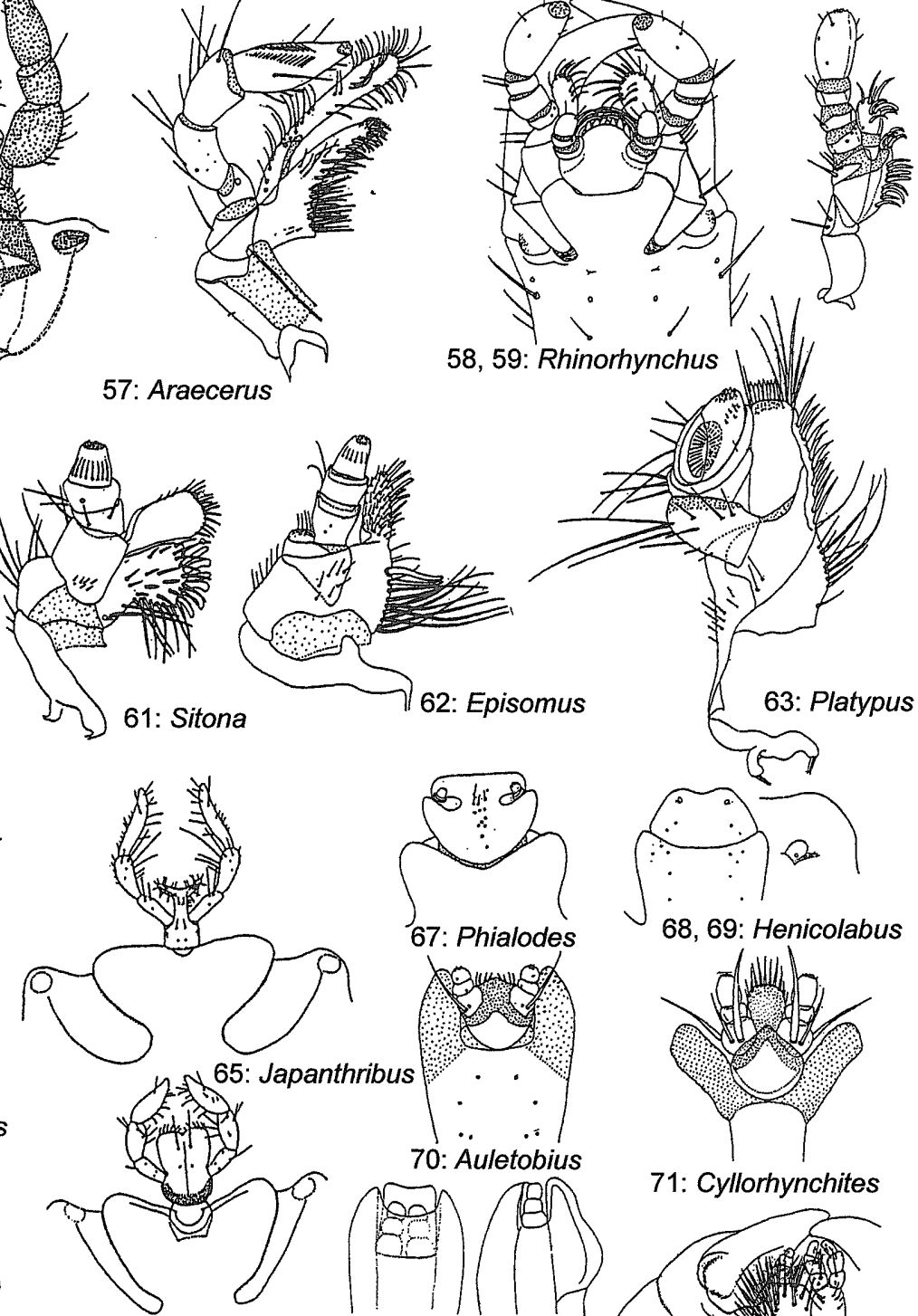

70: Auletobius

71: Cyllorhynchites

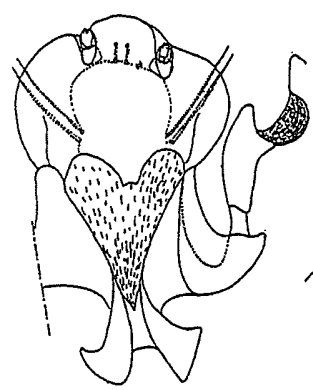

72: Cylas

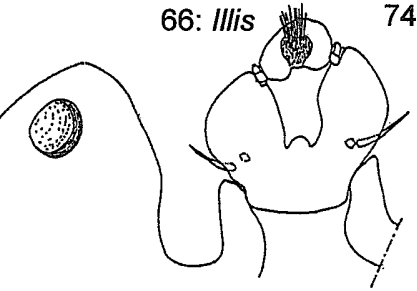

73: Cerobates

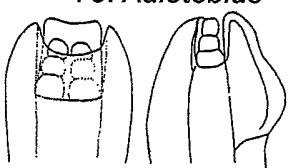

74, 75: Diocalandra
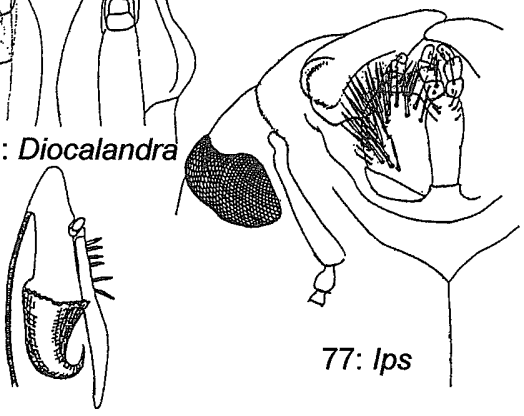

76: Sipalinus 


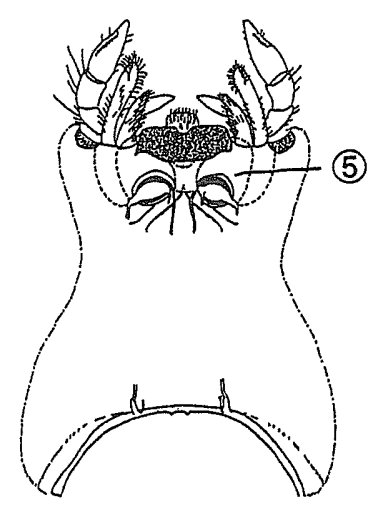

78: Euparius

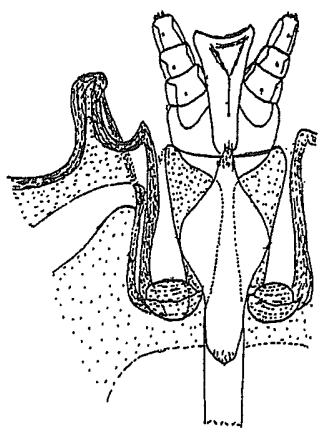

81: Rhinotia

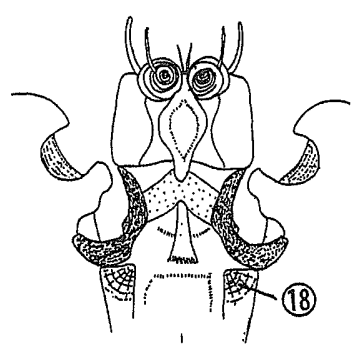

84: Ithycerus

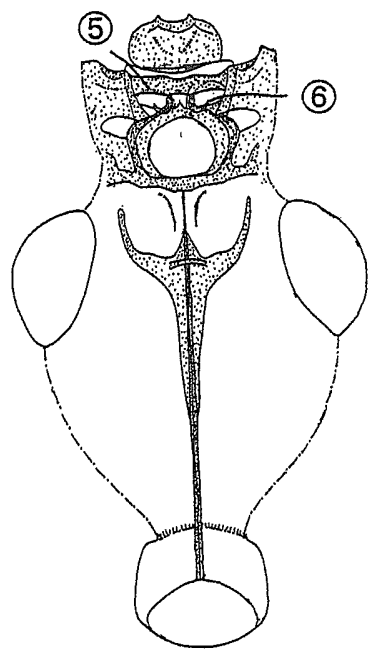

79: Apoderus

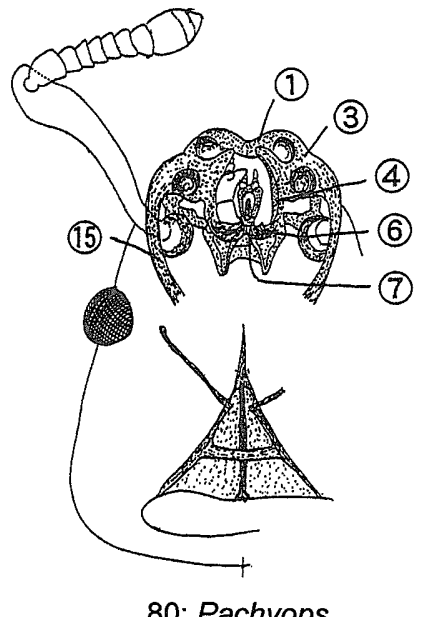

80: Pachyops

86: Sitona

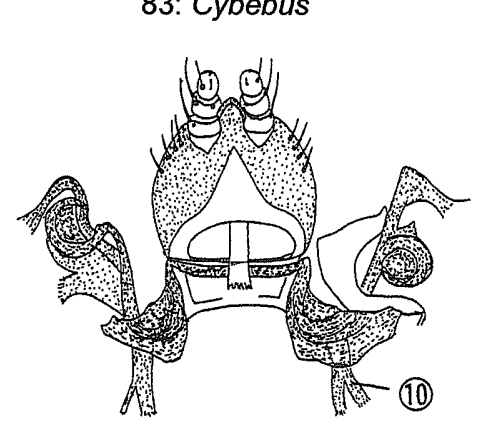

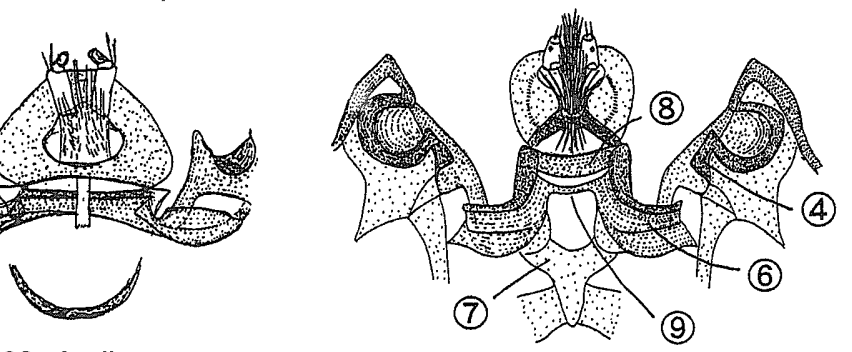

83: Cybebus
85: Brachycerus

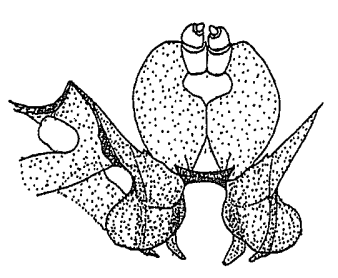

82: Aralius 


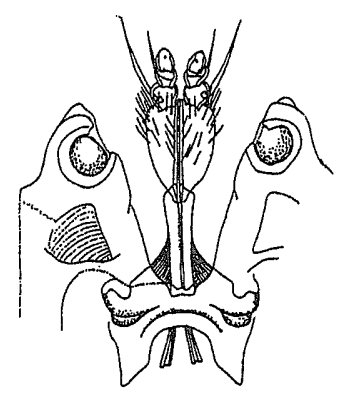

87: Desmidophorus

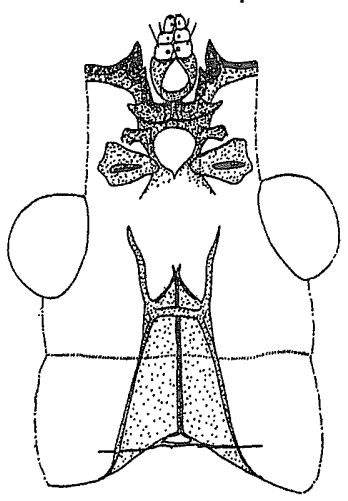

90: Phyllobius

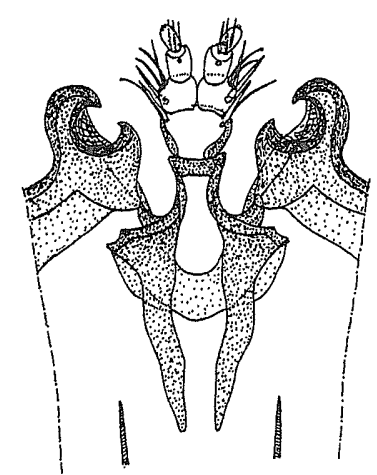

88: Pissodes

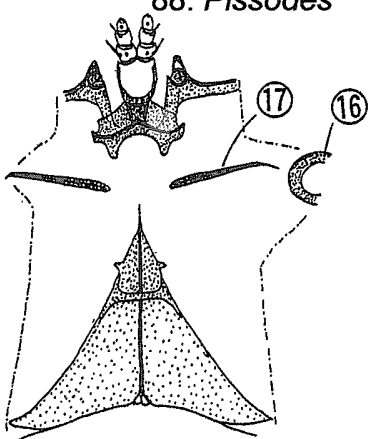

91: Polydrusus

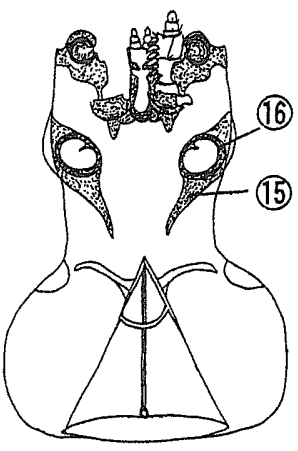

89: Cossonus

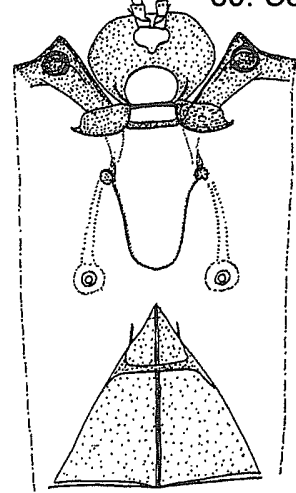

92: Metapocyrtus
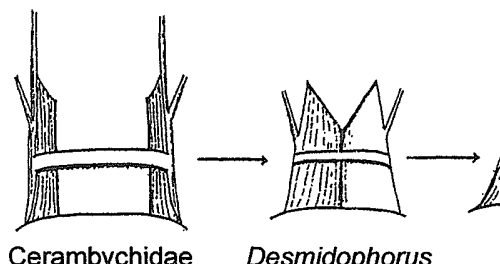

Cerambychidae Belidae

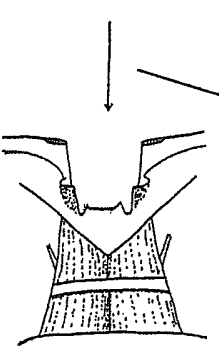

Scolytidae

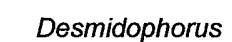

Desmidophorus

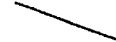

Brentidae, Ithyceridae, Antliarhininae,

Nanophyidae, Attelabidae (-Apoderini),

Apionidae, Curculionidae, Dryophthoridae

Apoderini
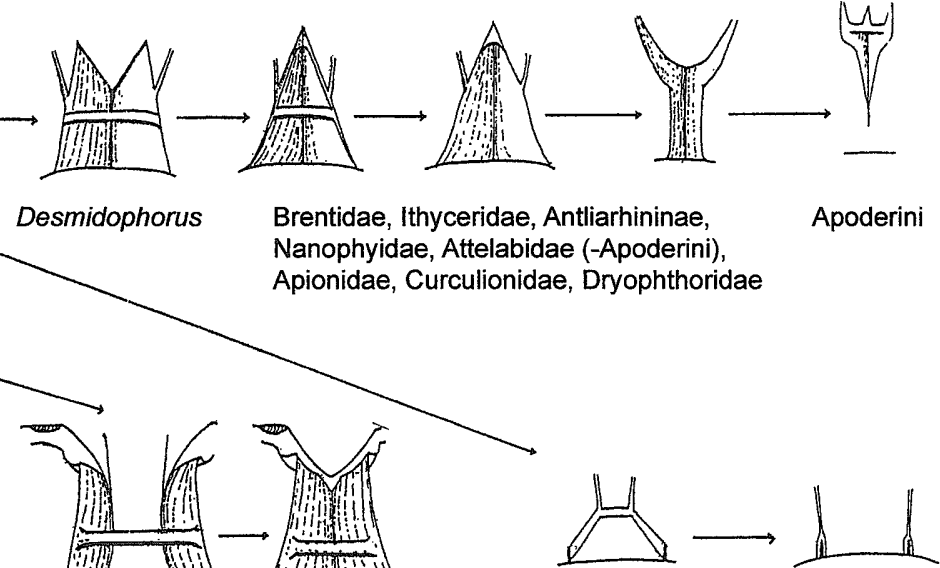

Oxycorynidae Anthribidae, Nemonychidae, Aglycyderinae

93: Progressive differentiation of tentorium, a schema 


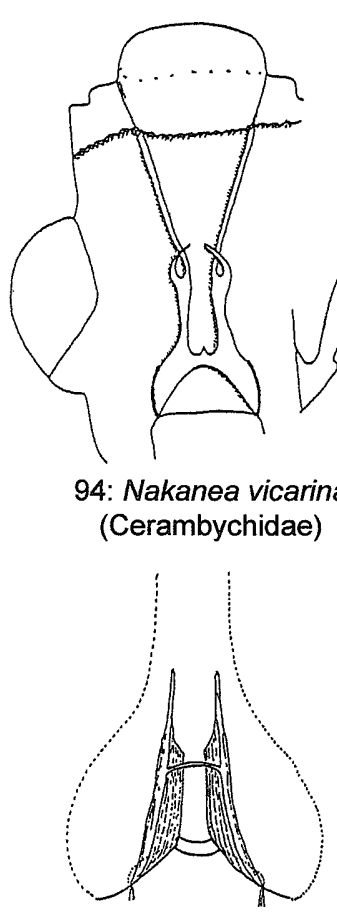

95: Rhinotia

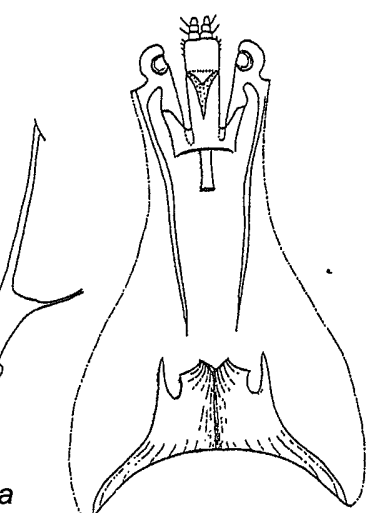

98: Desmidophorus
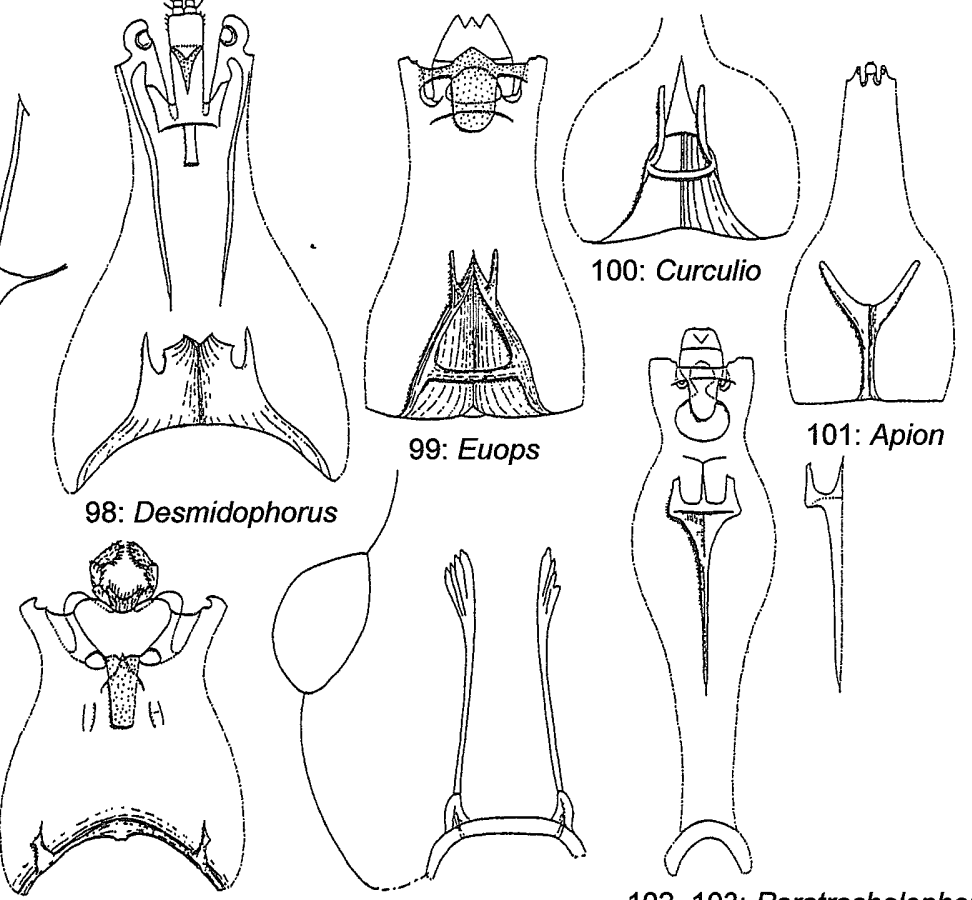

96: Tropideres

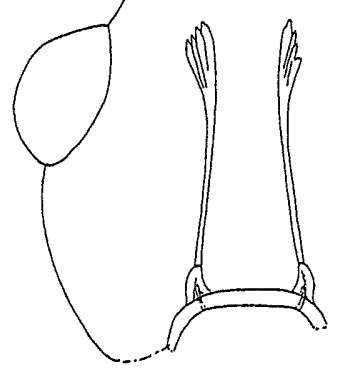

97: Rhinorhynchus

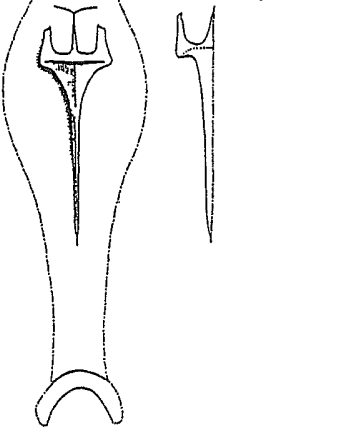

102, 103: Paratrachelophorus (r)

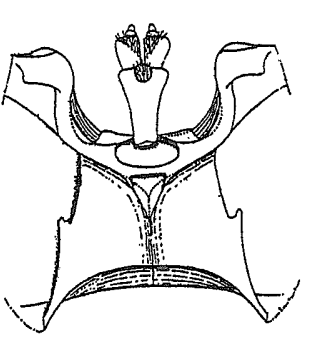

104: Xyleborus
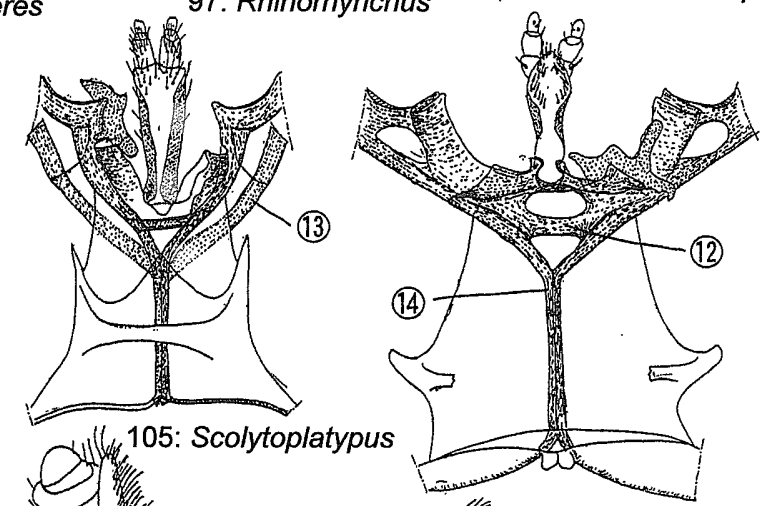

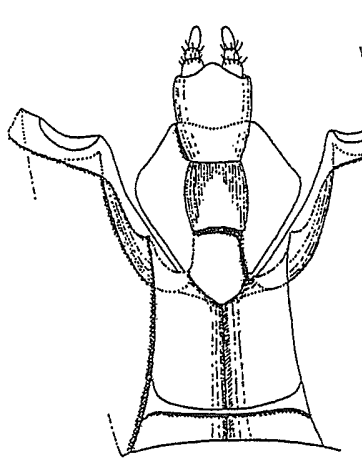

107: Platypus modestus

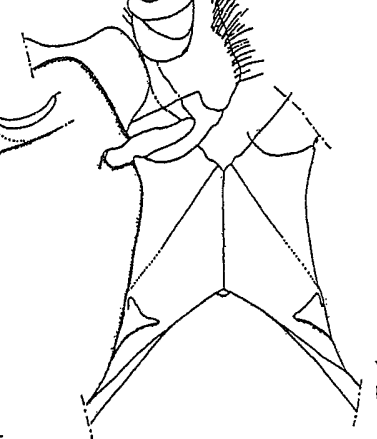

108: Platypus lewisi

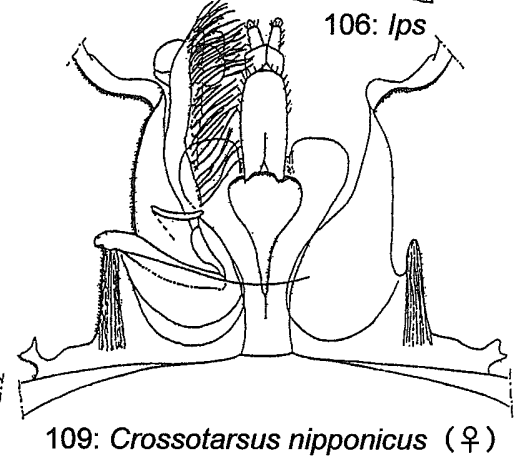

109: Crossotarsus nipponicus (우) 


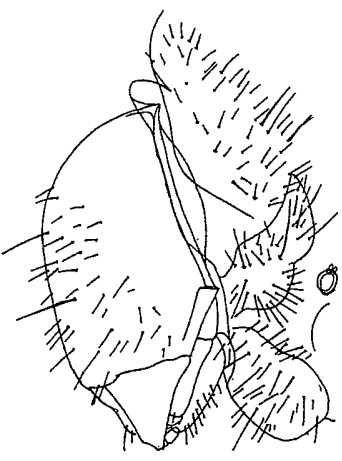

110: Araecerus

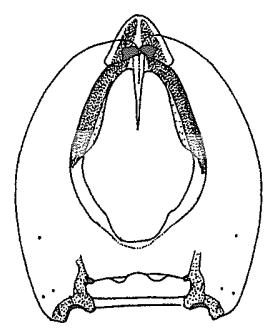

114: Scolytus

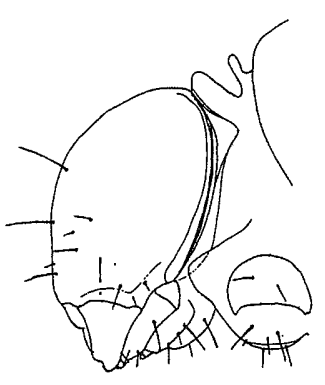

118: Cylas

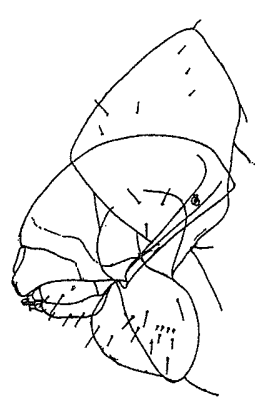

111: Byctiscus

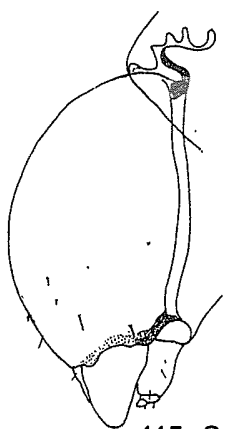

115: Scolytus

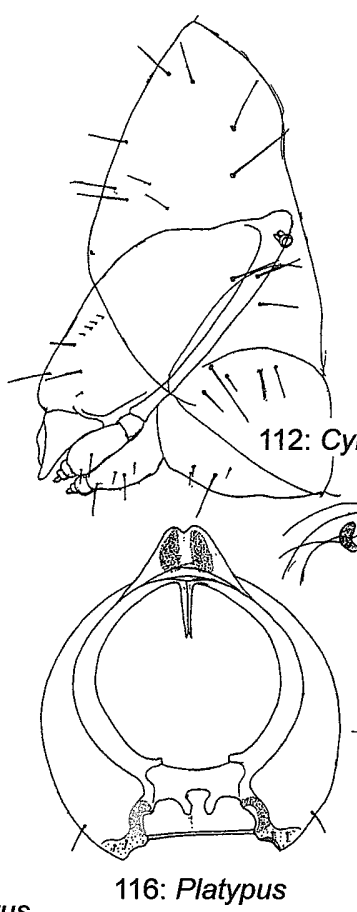

116: Platypus

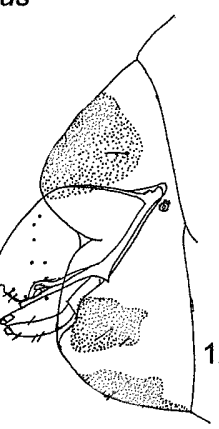

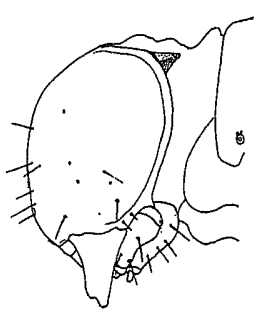

119: Baris

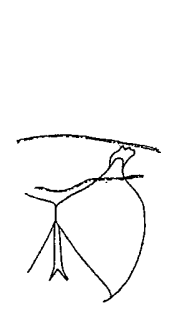

120: Orchestes

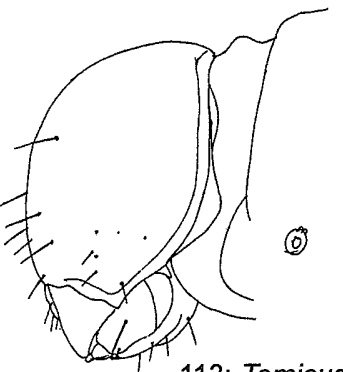

113: Tomicus
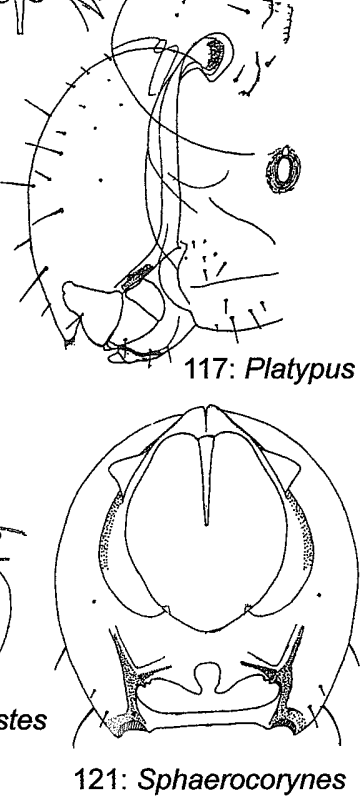

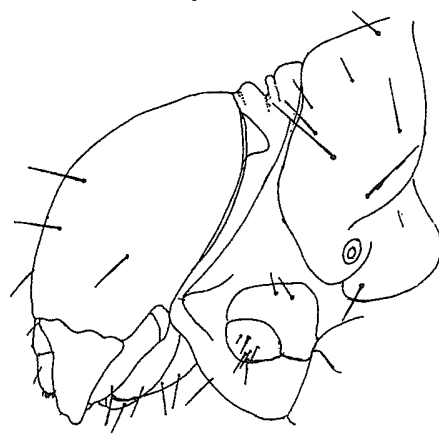

122: Shirahoshizo
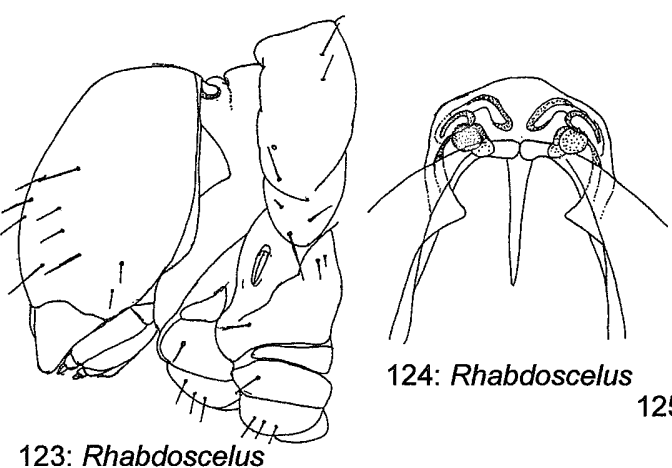

124: Rhabdoscelus

121: Sphaerocorynes 
Table 1. Data matrix

\begin{tabular}{llll}
\hline & 0 & 1 & \\
& 12345678901234567890123456 \\
\hline Hypo.ancestor & 00000000000000000000000000 \\
Nemonychidae & 10000000000000000000001000 \\
Anthribidae & 00222010000000000000002000 \\
Belidae & 00000101100000000000100000 \\
Oxycorynidae & 00000100000000000000001000 \\
Rhynchitide & 00000100100010000000004200 \\
Attelabidae & 10221110110010000010104200 \\
Ithyceridae & 01100121100011110011114200 \\
Brentidae & 01110121101111210013114200 \\
Apionidae & 01110121101111210011114200 \\
Nanophyidae & 01100121101111210011114201 \\
Brachyceridae & 01110121101111210011114200 \\
Dryophthoridae & 01110121101111210112114201 \\
Curculionidae & 01110121101111210011114201 \\
Scolytidae & 10220101010011110011103111 \\
Platypodidae & 10220101010011111011003121 \\
\hline
\end{tabular}

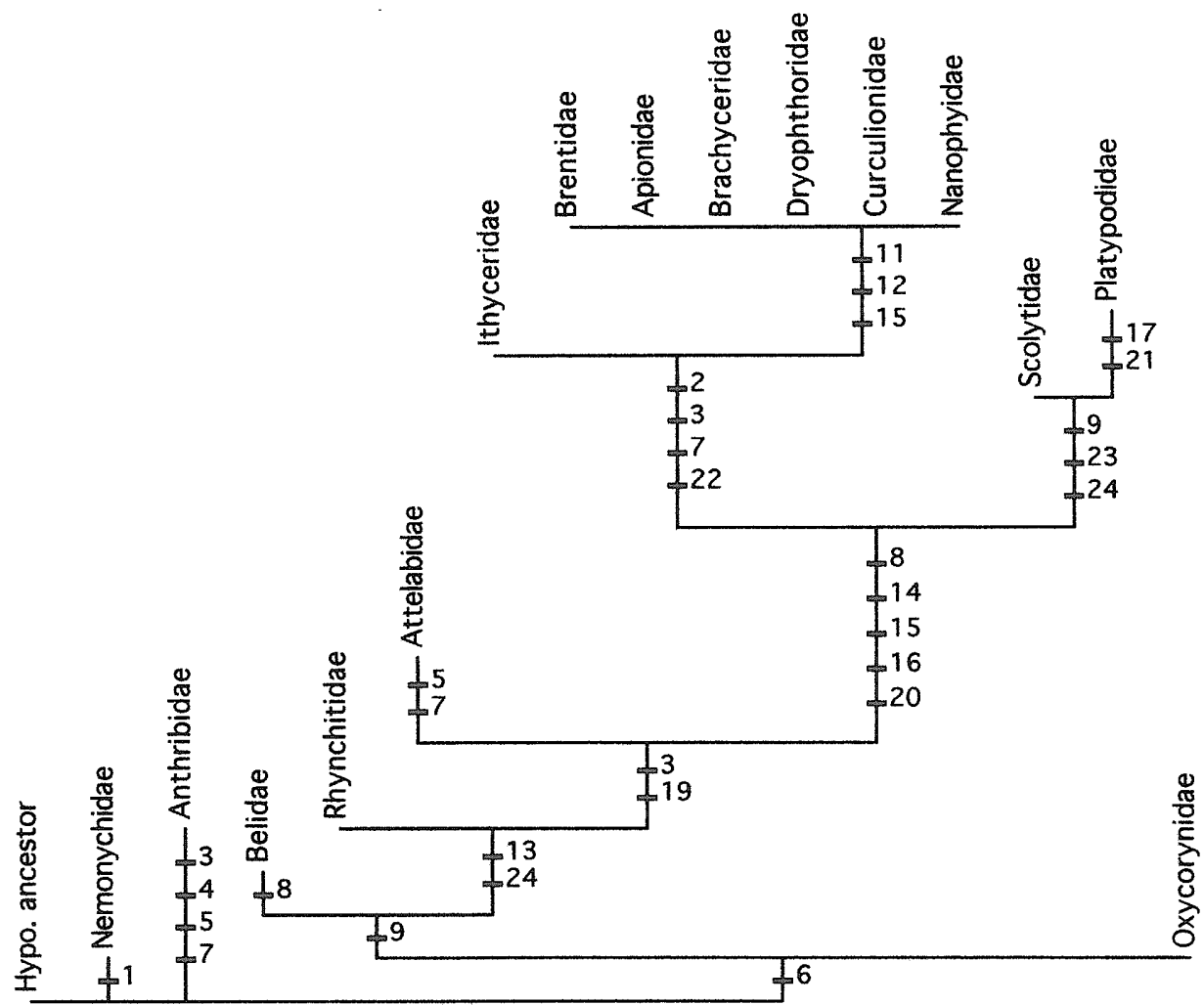




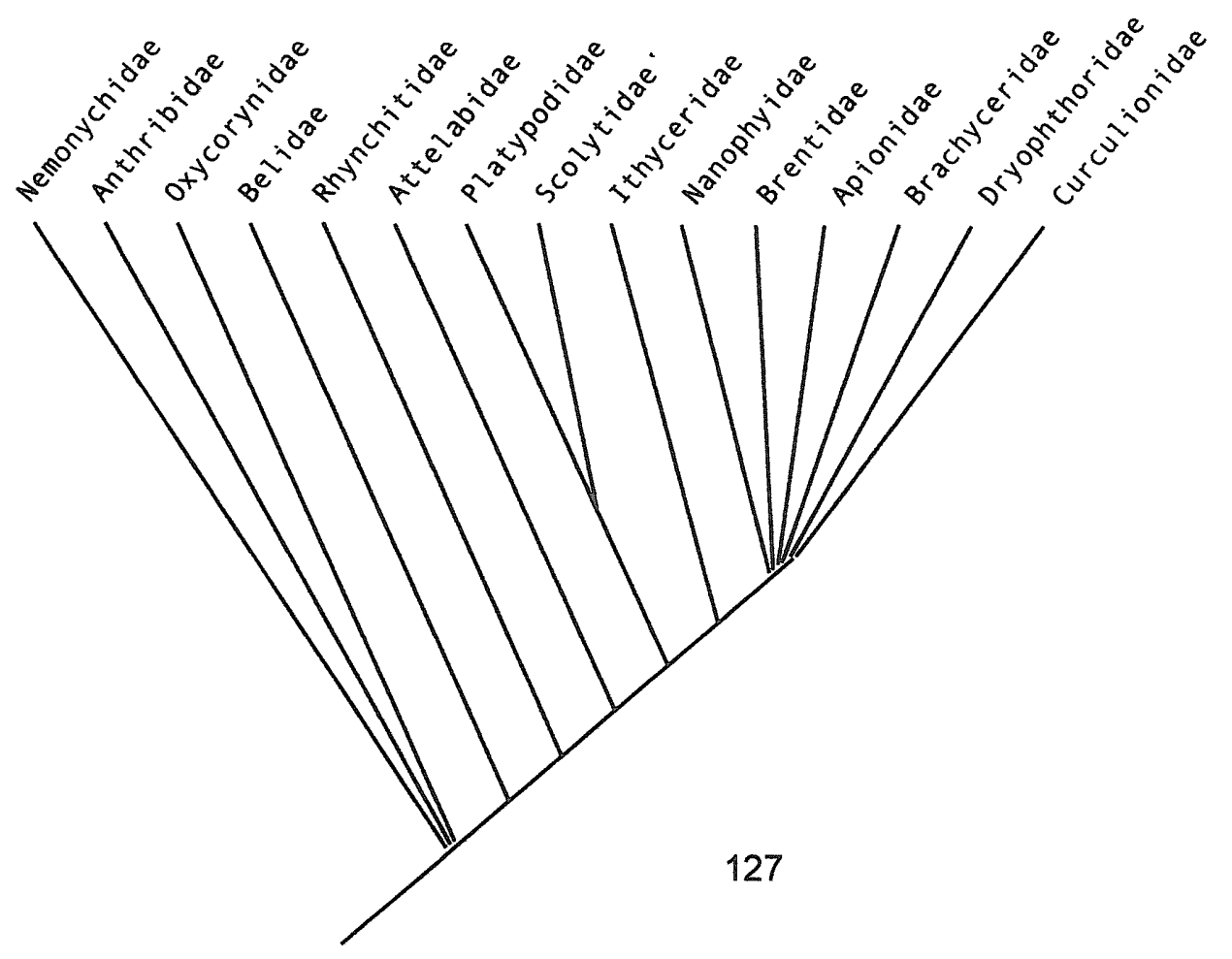




\section{"}

